\title{
6331 Sayılı İş Sağlığı ve Güvenliği Kanunu Bağlamında Soma Madenlerinin İ̧ Sağlığı ve Güvenliği Açısından Değerlendirilmesi
}

\section{Evaluation of Occupational Health and Safety Soma Mines in the Context of Occupational Health and Safety Law No. 6331}

\section{Atanur Karaahmetoğlư ${ }^{1}$}

Öz

$\mathrm{Bu}$ araştırmanın amacı, Soma madenlerinde uygulanan iş sağlığı ve güvenliği yöntemlerinin olumlu ve olumsuz etkisini analiz etmektir. Bu doğrultuda, Soma madenlerinin jeolojik yapısı, coğrafi konumu, uygulanan üretim teknikleri, istihdam modeli. Soma maden sahasında oluşturulan iş sağlığı ve güvenliği sistemi açısından incelemeler yapılmıştır. TKi verilerine göre, Soma madenlerinin yaklaşık 600 milyon ton kadar linyit kömürü rezervi bulunmaktadır. Bu nedenle, Soma madenlerinde geniş çaplı linyit üretimi yapılmaktadır. Soma madenlerinde yoğun bir üretimin yapılması, iş sağı̆ğı ve güvenliğini tehdit eden birçok riski de beraberinde getirmektedir. Ayrıca, araştrrmada Soma madenleri yerinde incelenmekle birlikte, bölgede bulunan uzman ve görevlilerin görüşlerine de başvurulmuştur. Bu şekilde Soma madenlerinde uygulanan iş sağlığı ve güvenliği politikalarının yeterli olup olmadığı konusu tartışımıştır. Bunun yanında, iş sağlığı ve güvenliği uygulamaları açısından Soma maden faciası sonrası dönem ile Soma maden faciası öncesi dönem mukayese edilmiştir. Sonuç olarak, Soma maden faciası öncesi dönemde görülen ihmallerin ve eksikliklerin giderilmesine dönük gerekli adımların atılıp atılmadığı üzerine incelemeler yapılmıştır.

\section{Anahtar Kelimeler}

Soma madenleri • İş sağlığı ve güvenliği • Önleyici sistem • Koruyucu tedbirler • İş sağlığı ve güvenliği anlayışı

\section{Abstract}

The aim of this study is to analyze the positive and negative effects of occupational health and safety methods applied in Soma mines.In this direction, the geological structure of Soma mines, geographical location, applied production techniques, employment model, occupational health and safety system in Soma mining site were examined. According to TKI data, Soma mines have about 600 million tons of lignite coal reserves. Intensive production in Soma mines brings many risks that threaten occupational health and safety. In addition, Soma mines were investigated on site and the opinions of experts and officials in the

1 Sorumlu Yazar: Atanur Karaahmetoğlu (Arş. Gör.), Kırklareli Üniversitesi, İktisadi ve İdari Bilimler Fakültesi, Çalışma Ekonomisi ve Endüstri İlişkileri Bölümü, İş Hukuku ve Sosyal Güvenlik Hukuku, Kırklareli, Türkiye. Eposta: atanurkartal@hotmail.com ORCID: 0000-0001-8306-3178

Atıf: Karaahmetoglu, A. (2019). 6331 sayılı iş sağlığı ve güvenliği kanunu bağlamında Soma madenlerinin iş sağlığı ve güvenliği açısından değerlendirilmesi. Sosyal Siyaset Konferansları Dergisi, 76, 89-128. https://doi.org/10.26650/jspc.2019.76.0005 
region were also investigated. In this way, it is discussed whether the occupational health and safety policies applied in Soma mines are sufficient.Besides, in terms of occupational health and safety practices, the period before Soma mine disaster and the period after Soma mining disaster were compared.As a result, investigations have been made on whether the necessary steps have been taken to eliminate the omissions and shortcomings seen in the period before the Soma mining disaster.

\section{Keywords}

Soma mines - Occupational health and safety - Preventive system - Protective measures - Occupational health and safety understanding 


\section{Extended Summary}

In general, mines are areas where many hazards are encountered. Especially in the mines, incidents of collapse and explosion are common. In addition, the structural properties of the mines also affect the emergence of this situation.

In this direction, it is very important to take preventive measures in order to prevent deaths and injuries in mines. For this reason, the mines need to be strengthened against the risk of accidents. One of the biggest hazards in mines is the risk of explosion. Therefore, it is of great benefit to take sequential security measures. In this context, the employer is required to take all precautions to avoid accidents at the mine. However, it is not enough for the employer to take measures alone.

It is a fact that, in mines workers need to be very careful. Otherwise, the worker puts his life and his friends at risk. The way to reach this consciousness of workers is through occupational health and safety training. Therefore, it is very important that employers provide occupational health and safety training to workers.

With the entry into force of the Occupational Health and Safety Law No. 6331, a new occupational health and safety concept has been adopted. Accordingly, the risk is not expected to occur and measures are taken in advance. For this reason, risk assessment is performed and the possible risks are recorded. Risks are minimized by risk assessment. This is why risk assessment needs to be done at every stage of mining. In this way, a significant reduction in potential accidents in mines is possible. After the Soma mine disaster, it has been the subject of controversy whether Soma mines have adequate risk assessment. Therefore, the question of whether there is negligence in the accident after Soma mine disaster has come to the agenda.

The general opinion was that there was a major negligence in the Soma mine disaster and there was not enough attention to occupational health and safety. Therefore, it is understood that the methods that should be followed in terms of occupational health and safety in Soma mines are not fully implemented. In this respect, some methods need to be implemented to ensure occupational health and safety. 
First of all, the employer has to take all necessary measures for occupational health and safety. In this respect, it is very important that the employer takes all protective and preventive measures.

For this reason, the employer is obliged to provide a working environment in which occupational health and safety measures are taken. In addition, the employer should keep the working environment under constant surveillance.

Secondly, the employer must provide all tools, equipment and protective equipment to protect workers against potential hazards. In addition, the employer must inform the workers regularly. Therefore, it is very important to provide these protective equipment to the workers in Soma mines. Because there are many danger areas within the mines.

Finally, the employer should regularly provide occupational health and safety training to employees. In this way, employees will have learned the correct behavior models. When there is a risk of an accident in the mine, for example in case of an explosion or fire hazard, workers who are trained in occupational health and safety will be more careful. Therefore, occupational health and safety trainings contribute to the reduction of occupational accidents and occupational diseases. However, there are other important issues for the establishment of occupational health and safety in mines.

In this direction, it is very important to create ventilation system in mines, to make fortifications, to fight with fire and explosion and to apply first aid techniques. However, the application of these techniques varies according to the structure of the mine and the production model monitored. For example, Soma mines are suitable for the structure and the machines are used more effectively in the production stage of the mine. For this reason, there are mechanized feet in Soma mines. Besides, methane gas is not high in Soma mines. However, the air pressure in Soma mines is high and the pressure must be controlled. Therefore, it is of great importance to monitor the occupational health and safety policy in Soma mines.

As a result, the occupational health and safety methods applied in Soma mines were not sufficient until the Soma mine disaster occurred in 2014. In Soma mines, it was examined whether there is a change in occupational 
health and safety policies applied in mines after the Soma mine disaster. In this respect, the occupational health and safety methods in Soma mining site was investigated in 2018. 


\section{Sayılı İş Sağlığı ve Güvenliği Kanunu Bağlamında Soma Madenlerinin İş Sağlığı ve Güvenliği Açısından Değerlendirilmesi}

İş sağlı̆̆ diğer kişilerin sağlığının korunması anlamına gelmektedir. İş güvenliği ise, işin güvenli bir ortam içinde yapılması ve sürdürülmesi anlamına gelmektedir (Şen, 2015: 120). Bu nedenle, iş güvenliği kavramı, çalışanların dışında, üretimin ve işletmenin de güvenliğinin tesis edilmesi anlayışının bir ürünüdür (Selek 2018: 27).

İş sağlığı ve güvenliği kavramı, "iş sağlığı" ve "iş güvenliği” kavramlarının ikisini ele bünyesinde barındıran bir kavramdır. Bu doğrultuda, iş sağlığı ve güvenliği kavramı, çalışanların sağlıklı ve güvenli bir şekilde çalışabilmesi için tıbbi ve teknik açıdan önlemler alınmasını amaçlayan bir sistemdir. $\mathrm{Bu}$ nedenledir ki iş sağlığı ve güvenliği, çalışanların sağlığını korumak üzere bir dizi önlem alındığı uygulamalar bütünüdür (Sümer, 2017: 5-7;Öztürk, 2015: 16-19).

İş sağlığı ve güvenliği kavramının, dar anlamda iş sağlığı ve güvenliği ve geniş anlamda iş sağlığ 1 ve güvenliği olmak üzere iki şekilde tanımlanması mümkün bulunmaktadır (Tiftik ve Adıgüzel, 2016: 330-333). Bu bağlamda, dar anlamda iş sağlığı ve güvenliği, çalışanın bedenen ve ruhen sağlığının zarar görmemesi açısından muhtemel iş ve işyeri kaynaklı risklerin bertaraf edilmesi anlamına gelmektedir (Şen, 2015: 124). Bu nedenle, iş sağlığ1 ve güvenliği açısından çalışanların risklere karşı korunması için işverene büyük görev düşmektedir. Ancak, ülkemizde iş sağlı̆̆1 ve güvenliği mevzuatı şekillenirken çalışanların ruh sağ lı̆̆ından ziyade, beden sağlığının korunması ön planda tutulmuştur. Geniş anlamda iş sağlığı ve güvenliği kavramı ise, işçilerin korunması açısından devlete de sorumluluk yükleyen bir amaca hizmet etmektedir (Balkır, 2012: 59). Burada devlete düşen görev, yapmış olduğu ve yapacağ yasal düzenlemelerle işveren karşısında işçinin konumunu güçlendirmek, bu şekilde işyerlerinde iş sağlığ ve güvenliğinin oluşmasına katkıda bulunmaktır (Süzek, 2017: 891).

$\mathrm{Bu}$ doğrultuda, iş sağlığı ve güvenliği çalışanların iş kazası ve meslek hastalıkları risklerine karşı korunmasını ve ileride görülmesi muhtemel yıkıcı ve yıpratıcı tehlikelere karşı korunması amacıyla gerekli önlemlerin alınması anlamına gelmektedir (Sümer, 2017: 6-7;Öztürk, 2015: 16-19). Bir başka ifadeyle iş sağlığı ve güvenliği, işyerinde üretimin bütün safhalarında 
çalışanların her türlü tehlikelere karşı korunması için gerekli tüm maddi ve manevi önlemlerin alındığı çok yönlü ve sistemli çalışmalar bütünüdür (Akpınar, 2018: 5). Bu nedenle, çalışanların iş kazası ve meslek hastalıklarına maruz kalmaması için alınacak bu tedbirler büyük önem taşımaktadır (Narter, 2017: 163). Alınan önlemler ile çalışanlar sağlıklı bir fiziki ortamda güven içinde bulunmaktadır (Eyrenci vd., 2017: 347). Dolayısıyla, iş sağlı̆̆1 ve güvenliği işverenin çalışanlarını korumaya yönelik önlemler almasını ifade etmektedir. Ayrıca, işverenin bu yükümlülügü sadece kendi işçileri ile sınırlı değildir. Bunun yanında, işverenin kendi işyerinde geçici iş ilişkisi ya da alt işverenlik ilişkisi ile çalıştırdığg diğer işçilere karşı da iş sağlığ1 ve güvenliğini tesis etme yükümlülüğü bulunmaktadır (Balkır, 2012: 59). Bu nedenle, önemine binaen iş sağlı̆̆ı ve güvenliği uygulamaları madenlere yönelik yapılan kanuni düzenlemelerde de göz ard1 edilmemiştir (Turhan, 2016: 31).

Ulusal mevzuatımızda iş sağlığı ve güvenliği alanında ilk önemli gelişmeler maden işçilerine yönelik, sanayileşme hareketinin başladığı 19. yüzyılda yaşanmıştır. Bu nedenle, Osmanlı Devleti döneminde iş sağlığı ve güvenliği alanında ilk kanuni düzenlemeler maden işçilerine yönelik hazırlanmıştır (Baybora, 2012: 7; Özveri, 2012: 25). Örneğin, 1865 yılında yürürlüğe giren Dilaver Paşa Nizamnamaesi ile madenlerde iş sağlı̆̆ 1 ve güvenliğini sağlamak açısından ilk önemli düzenlemeler yapılmış ve Dilaver Paşa Nizamnamesi ile madenlerde iş kazası ve meslek hastalıklarını önlenmesi amaçlanmıştır (Akdeniz, 2015: 7-8). Osmanlı Devleti'nde bu dönemde yürürlüğe giren bir diğer Nizamname olan 1869 tarihli Nizamnamede de madenlerde iş sağlı̆̆ 1 ve güvenliğinin sağlanması hedeflenmiştir (Güzel vd., 2016: 24). Aynı şekilde Cumhuriyet dönemde de yapılan mevzuat çalışmalarıyla iş sağlığı ve güvenliği alanındaki gelişmeler devam etmiştir. Ancak, iş sağlığı ve güvenliği alanında asıl büyük adım 2012 yılında atılmıştır. 2012 yılı, iş sağlığ1 ve güvenliği açısından bir dönüm noktası olmuştur. Bu doğrultuda, 20.06.2012 tarih ve 6331 sayılı İş Sağlığı ve Güvenliği Kanunu (RG: T.30.06.2012, S. 28339) kapsamında iş sağlığ 1 ve güvenliği konusu ilk defa özel olarak tek bir kanunda düzenlenmiştir. Zira, 6331 sayılı İSGK, iş sağlı̆̆1 ve güvenliği sistemini tüm yönleriyle ele almıştır (Karakaş, 2014: 101).

2012 yılına kadar iş sağlığı ve güvenliği alanında sistemli ve münhasıran bu alanı düzenleyen bir kanun bulunmamaktayd1. Dolayısıyla, 2012'ye kadar bu alanda çıkartılmış tüzük ve yönetmelikler uygulanmış ve bu konuya 
ilişkin bir kanuni düzenleme yapılmamıştır (Poyraz, 2016: 147). Bu şartların etkisiyle 2012 yılında 6331 sayılı İSGK yürürlüğe girmiş ve bu alanda yaşanan uyuşmazlıklarda ve bu uyuşmazlıkların çözüme kavuşmasında İSGK başvurulan temel kanuni dayanak halini almıştır (Yamakoğlu, 2016: 46). Ancak, maden işçileri açısından İSGK dışında, 3213 sayılı Maden Kanunu (RG: T.15.06.1985, S.18785) da önemli düzenlemeler getirmiştir. Maden Kanunu birçok maddesinde proje, ruhsat, işletme hakk1, rödovans sözleşmeleri, harçlar ve rezerv araştırması gibi konuları ele almakla birlikte, maden işçileri açısından oldukça önemli bir konu olan iş sağlığ 1 ve güvenliği konusu üzerinde de durmuştur. Bunun yanında, maden işyerlerinde iş sağlığ ve güvenliğinin tesisi için, Maden İşyerlerinde İş Sağlığı ve Güvenliği Yönetmeliği (RG: T. 19.09.2013, S. 28770) de yürürlüğe getirmiştir. Yönetmelik, maden işyerinde işverene iş sağlığı ve güvenliğini sağlama yükümlülügü yüklemiştir. Ancak, ilerleyen dönemde 301 işçinin acı şekilde hayatını kaybetmesine yol açan Soma maden faciası başta olmak üzere ülkemizde birçok maden kazasının yaşanması nedeniyle ülkemiz, ILO'nun (International Labour Organization) 176 sayılı Maden İşçilerinin Güvenliği ve Sağlığı Sözleşmesini (RG: T. 12.12.2014, S. 29203) onaylayıp iç hukuk sistemine aktarmıştır. Ayrıca, bu düzenlemelerin yapılmasında madenlerde yaşanan iş kazalarındaki artışların yanında, özellikle yer altı maden işletmelerinde taş, kömür ve cevher tozlarının bulunduğu ortamda çalışma şartları, madenci hastalığı olarak bilinen pnömokonyoz ve silikozis gibi hastalıkların sık görülmesi oldukça önemli rol oynamıştır (Türkiye Maden İşçileri Sendikası, 2010: 6).

Bu açıklamalar doğrultusunda, 6331 İSGK'nin benimsediği yeni iş sağlığ1 ve güvenliği anlayışını ele almak isabetli olacaktır. Zira, 6331 sayılı ISSGK'nin yürürlüğe girmesi ile birlikte, iş sağlığ ve güvenliği anlayışında önemli gelişmeler yaşanmıştır.

\section{Sayılı İSGK Perspektifinden İş Sağlığı ve Güvenliği Anlayışı}

6331 sayılı İş Sağlığı ve Güvenliği Kanunu (İSGK)genel yapısı itibarıyla, işverene çalışanın sağlığını ve güvenliğini koruma borcu yüklemiştir (Eyrenci, vd., 2017: 366; Şen, 2015: 136). Bu doğrultuda işveren, çalışanın vücut bütünlüğünü ve beden sağlı̆̆ını korumak adına azami dikkat ve özeni göstermekle yükümlü tutulmuştur (Süzek, 2017: 907-908;Sümer, 2017: 105;Baybora, 2012: 10-11;Özveri, 2015: 84). İşverenin bu yükümlülüğü 
aynı zamanda, işçiyi koruma ve gözetme borcunun da bir gereğidir (Alper ve K1lkış, 2017: 68;Öztürk, 2015: 11-12). Bu bağlamda işverenin iş kazası ve meslek hastalıklarını önlemek açısından çalışma ortamını gözetlemesi, sürekli değişen risk ve tehlikeleri tespit etmesi ve önlem alması gerekmektedir (Selek, 2018: 328). Bu doğrultuda işveren, çalışma ortamında düzenli olarak denetimler yapma mükellefiyeti altında bulunmaktadır (Özdemir, 2012: 60). 6331 sayılı İSGK'nin yürürlüğe girmesi ile birlikte, 4857 sayılı İş Kanunu'nun (İşK.) iş sağlı̆ğ ve güvenliğini düzenleyen hükümleri, denetim ve kontrolü düzenleyen hükümler dışında yürürlükten kalkmıştır. İSGK m. 2 hükmü uyarınca, kamu ve özel sektöre ait bütün işlere ve işyerlerine, bahse konu işyerlerinin işverenleri ile işveren vekillerine, çırak ve stajyerler de dâhil olmak üzere tüm çalışanlarına faaliyet konularına bakılmaksızın kanunun uygulanacağı hükme bağlanmıştır. Dolayısıyla Kanun, İşK., DİK, BİK ve TBK kapsamında çalışan işçileri, çırak ve stajyerleri, memur, sözleşmeli personel ve diğer kamu görevlilerini kapsar nitelikte hükümler ihdas etmiştir (Tiftik ve Adigüzel, 2016: 333).

İSGK ile işverenin çalışanlarla ilgili sağl1k ve güvenliği sağlama yükümlülüğünün sınırları belirlenmek amaçlanmıştır (Akpınar, 2018: 261). İSGK m. 4 hükmü, işverenin çalışanların iş ile ilgili sağlık ve güvenliğini sağlamakla yükümlü olduğu belirtildikten sonra, yapacağı ve uymakla yükümlü bulunacağı birtakım esaslara yer verilmiştir. İSGK m. 5 hükmü ile de işverenin anılan yükümlülüklerle gerçekleştirirken çalışanları koruma açısından uyacağı yöntemler belirlenmiştir. İSGK m. 10 hükmünde ise, işyerinde sağlıklı ve güvenli bir ortamın tesisi için işverenin yapacağ risk değerlendirmesinde dikkate almakla yükümlü bulunduğu hususlar düzenlenmiştir. İSGK m. 15 hükmünde işverenin işyerinde çalışanlara yönelik sağlık gözetimi yapması gerektiği düzenlenmiştir. Bu düzenlemeler ile Kanun çalışanlara eğitim verilmesi, gerekli bilgilendirmelerin yapılması, güvenlik önlemlerinin her koşulda uygulanması, risk değerlendirmelerinin yapılması ve acil durum ve tahliye planlarının belirlenmesi yöntemleri ile işçi sağlı̆̆ının korunmasını amaçlamıştır ve konu kanuni bir zemine oturmuştur (Uluslararası Çalışma Örgütü, 2016: 69). Bu doğrultuda, Yargıtay bir kararında, işyerinde sağlıklı ve güvenli bir ortamın oluşması için İSGK uyarınca işverenin çeşitli yükümlülüklerinin bulunduğunu ve işverenin bu yükümlülüklerini yerine getirmemesi veya ihmali nedeniyle ortaya çıkacak olumsuz sonuçlardan dolayı sorumlu olacağını kabul etmiştir (Y.HGK, 
T.09.10.2013, E.2013/21-102, K.2013/1456). Yargıtay başka bir kararında işverenin ve işçinin yükümlülüklerini ele almıştır. Bu kapsamda Yargıtay 6331 sayılı İSGK çerçevesinde konuyu değerlendirmiştir. Yargıtay, 4857 sayılı İşK. mülga 77. vd. maddelerini yürürlükten kaldıran 6331 sayılı İSGK m. 4 ve m. 5 hükümlerinin işverene yüklenen yükümlülükleri, m. 19 hükmünün de çalışanların yükümlülüklerini güncel gelişmelerle uyumlu olarak daha ayrıntılı düzenlediğini belirtmiştir. Yargıtay’a göre, İSGK yapmış olduğu düzenlemelerle kusur sorumluluğunun sinırlarını kusursuz sorumluluğun sınırlarına yaklaştırmıştır (Y.21.HD, E. 2016/15802, K. 2017/3195, T.18.04.2017).

İşverenin iş sağlığı ve güvenliği önlemlerini alma yükümlülüğü İSGK dışında 6098 sayılı Türk Borçlar Kanunu (RG: T.04.02.2011, S.27836) nezdinde de hüküm altına alınmıştır. TBK'nin "İşçinin Kişiliğinin Korunması" başlığını taşıyan m. 417/2 hükmünde bu duruma işaret edilmiştir. Anılan hükme göre, "İ̧sveren, işyerinde iş sağlığı ve güvenliğinin sağlanması için gerekli her türlü önlemi almak, araç ve gereçleri noksansız bulundurmak, işçiler de iş sağlığg ve güvenliği konusunda alınan her türlü önleme uymakla yükümlüdür" şeklinde konu düzenlenmiştir. Bu doğrultuda, işverenin, işçinin kişiliğini korumak ve saygı göstermek, işçinin sağlı̆̆ını gözetmek üzere yükümlülüğü bulunmaktadır (Sevimli, 2013: 125). Buna göre işveren, hizmet ilişkisinin ve yapılan işin niteliği göz önünde tutulduğunda, hakkaniyet gereği kendisinden beklenen; denetimlerin zorunlu kıldığı, teknik açıdan uygulanabilir ve işyerinin özelliklerine uygun olan önlemleri almakla yükümlüdür. İşverenin bu yükümlülüklere uymaması sonucunda işçinin ölmesi durumunda, desteğinden yoksun kalanların bu yüzden uğradıkları zararlara karşıllı isteyecekleri tazminat, sözleşmeye aykırılıktan doğan sorumluluk hükümlerine tâbi olacaktır(Günay, 2012: 1281).

$\mathrm{Bu}$ doğrultuda, işveren, işçinin yaşamını, sağllğını ve bedensel bütünlüğünü korumak için gerekli tüm önlemleri almakla mükelleftir (Süzek, 2017: 908;Özdemir, 2014: 65-66). Bu bağlamda, işverenin, işçinin sağlığını ve hayatını tehlikeye düşürecek riskleri bertaraf ederek, işçilerine iş sağlığ ve güvenliği tehlikelerinin asgari seviyeye indirildiği bir işyeri ve çalışma ortamı hazırlama yükümlülüğü bulunmaktadır (Öztürk, 2015:, 11-12). Dolayısıyla, iş sağlığı ve güvenliğinin sağlanması için işverenin iş sağlığı ve güvenliğine dönük tüm önlemleri alma vecibesi bulunmaktadır (Özdemir, 2014: 65-66). Ancak, işverenin 
iş kazası ya da meslek hastalıkları yaşanmadan önleyici ve koruyucu tedbirleri alması gerekmektedir. Zira, 6331 sayılı İSGK'nin benimsediği iş sağlı̆̆ 1 ve güvenliği anlayışı, temelde iş kazası ve meslek hastalıkları yaşanmadan önceki evrede önlem alınması ve bu tedbirlerin uygulanması anlayışını benimsemiştir (Baybora, 2017: 163; Akpinar 2015: 103-105).

$\mathrm{Bu}$ açıklamalardan hareketle, iş sağlığı ve güvenliği açısından yeni bir anlayış benimsenmiştir. Bu yeni iş sağlığı ve güvenliği anlayışı ile maden işyerlerinde de birçok yeni uygulama hayata geçmiştir.

\section{Maden İşyerlerinde Yeni İş Sağlı̆̆ı ve Güvenliği Anlayışı}

İş sağlığı ve güvenliği anlayışı temelde çalışanın yanında, üretimin ve işletmenin de güvenliğini esas almaktadır (Selek, 2018: 27). Bu nedenle, ülkemizde İSGK'nin yürürlüğe girmesi ile birlikte önleyici ve koruyucu bir iş sağlı̆̆1 ve güvenliği sistemi oluşturmak istenmiştir (Yılmaz, 2013: 46-47). Bir başka ifadeyle, iş kazası ya da meslek hastalığı ortaya çıkmadan en baştan önleyici tedbirlerin alınması amaçlanmıştır (Şen, 2015: 128). Bu bağlamda maden işyerlerinde işverenin çalışma ortamında oluşabilecek risk ve tehlikeleri öngörmesi, bu risk ve tehlikelerin ortaya çıkmasını engellemesi ve çalışma ortamını bu şekilde oluşturması iş sağlığı ve güvenliği anlayışına uygun düşmektedir (Akpınar, 2015: 198-200). Bunun yanında işyerinin barındırdığı tehlike derecesi de işyerinde uygulanacak iş sağlığı ve güvenliği yöntemlerine etki etmektedir. Bu nedenle, İSGK'nin “Tehlike Sınıfının Belirlenmesi” başlıklı m. 9 hükmünde işyeri tehlike sınıflarının nasıl derecelendirileceği ve nasıl tespit edileceği düzenlenmiştir. Bu doğrultuda, Aile ve Çalışma Sosyal Hizmetler Bakanlığı tarafindan çıkartılan İş Sağlığı ve Güvenliğine İlişkin Tehlike Sınıfları Listesi Tebliği (RG: T. 26.12.2012, S. 27417) ile işyerleri, tehlikeli, az tehlikeli ve çok tehlikeli işyerleri olmak üzere bir sınıflandırmaya tabi tutulmuştur. İSGK, m. 4 hükmünde işverenlere iş sağlıği ve güvenliği açısından genel yükümlülükler yüklenmiştir. Bunun dışında, İSGK m. 6 hükmünde işyerinin tehlike sınıflandırmasına göre işverene ek yükümlülükler yüklenmiştir.

6331 sayılı İSGK 6/1-a hükmünde, "Çalışanları arasından iş güvenliği uzmanı, işyeri hekimi ve on ve daha fazla çalışanı olan çok tehlikeli sinıfta yer alan işyerlerinde diğer să̆llk personeli görevlendirir. Çalışanları arasında belirlenen niteliklere sahip personel bulunmaması hâlinde, bu 
hizmetin tamamını veya bir kısmını ortak sağlı ve güvenlik birimlerinden hizmet alarak yerine getirebilir. Ancak belirlenen niteliklere ve gerekli belgeye sahip olması hâlinde, tehlike sınıfi ve çalışan sayısı dikkate alınarak, bu hizmetin yerine getirilmesini kendisi üstlenebilir. (Ek cümle: 10/9/20146552/16 md.) Belirlenen niteliklere ve gerekli belgeye sahip olmayan ancak 50'den az çalışanı bulunan ve az tehlikeli sinıfta yer alan işyeri işverenleri veya işveren vekili tarafindan Bakanlıkça ilan edilen eğitimleri tamamlamak şartıyla işe giriş ve periyodik muayeneler ve tetkikler hariç iş sağlığı ve güvenliği hizmetlerini yürütebilirler" şeklinde tehlikeli işyerleri açısından bir düzenleme yapılmıştır.

Tehlikeli ve çok tehlikeli işyerlerinde çalışmak oldukça risklidir. $\mathrm{Bu}$ nedenle, tehlikeli ve çok tehlikeli işyerlerinde çalışacak çalışanların, bu işyerlerinde çalışmaya elverişli olduklarını sağlık raporları ile belgelemeleri gerekmektedir. Bu bağlamda madencilik faaliyetlerinin tamamı tehlikeli, az tehlikeli ve çok tehlikeli işyerleri şeklinde yapılan sınıflandırmada, çok tehlikeli işyerleri kategorisi içinde yer almaktadır. Bunun nedeni madenciliğin yoğun emek isteyen, birçok risk içeren bir özellik göstermesidir (Selek, 2018: 259-260; Uluslararası Çalışma Örgütü, 2016: 60).Bunun yanında, 176 sayılı ILO Sözleşmesinde de, işverenin tehlikelerin meydana gelmesi muhtemel bölgeler için güvenli bir çalışma organizasyonu ve işçilerin korunmasını sağlamak üzere bir işletme planı ve işletme prosedürleri oluşturması ve uygulamas1 gerekliliği düzenlenmiştir (https://www.ilo.org).

İSGK ile getirilen düzenlemeler ülkemizde tüm iş kollarında etkisini göstermiştir. Madencilik ve taş ocakları işkolunda da İSGK'nın getirmiş olduğu birçok yeni düzenleme uygulama alanı bulmuştur. Kanun ile madenlerde iş sağlığı ve güvenliği önlemlerinin uygulanmasını sağlamak amacıyla yapılan denetimler arttırılmıştır. Ülkemizde, madenlerde gerekli denetimleri yapan kuruluş Enerji ve Tabii Kaynaklar Bakanlığı Maden İşleri Genel Müdürlüğüdür. Ancak, madenlerde iş sağlı̆̆ ve güvenliği denetimlerini ise, Aile ve Çalışma Sosyal Hizmetler Bakanlığı yapmaktadır. Ülkemizde, İSGK dışında, Maden Kanunu da madenlerde iş sağlığı ve güvenliğinin sağlanması açısından önemli düzenlemeler getirmiştir. Maden Kanunu'nda, iş sağlığı ve güvenliği açısından düzenlenen temel konuların başında, "Daimi Teknik Nezaretçi” sıfatıyla işletmede sürekli olarak maden mühendislerinin zorunlu istihdamına yönelik düzenlemeler olmuştur (Gerek, 2014: 2). 
Böylece, madenlerde arama faaliyetlerinde çalıştırılan işçilerin denetlenmesi ve kontrol edilmesi amaçlanmıştır (Uluslararası Çalışma Örgütü, 2016: 69).

$\mathrm{Bu}$ açıklamalar çerçevesinde işveren, iş sağlığı ve güvenliği önlemlerini tesis etmekle birlikte, sağllk ve güvenlik tedbirlerini de değişen şartlara uyumlu hale getirme mecburiyeti altında bulunmaktadır (Sümer, 2017: 105106; Özdemir, 2014: 101). Bu bağlamda, işverenin teknolojik gelişmeleri takip ederek, teknolojik gelişmeler doğrultusunda iş sağlığı ve güvenliği sistemini yenilemesi ve bu yeni sistem hakkında çalışanlarını bilgilendirmesi gerekmektedir(Özdemir, 2017:647;Akpınar,2018: 109). Dolayısıyla, işyerinde iş sağlığı ve güvenliği sisteminin oluşturulmasında ve uygulanmasında en temel vazife işverene düşmektedir (Korkmaz ve Alp, 2017: 314). Bunun yanında, işyerinde uygulanacak olan iş sağlığı ve güvenliği politikaları, işverenin faaliyet gösterdiği işyeri veya işletmenin ekonomik, teknik ve mali özelliklerine göre farkl11ık göstermektedir (Kaplan, 2015: 340). Bu nedenledir ki, yer altı, yer üstü maden işyerleri ve sondajla maden çıkartılan işyerleri açısından işyerinin özelliğinden dolayı işverenin havalandırma, tahkimat, gaz ve tozdan arındırma, yangın ve patlamayla etkin mücadele, çıkış tünelleri yapma, ortam sıcaklığını dengeleme, gibi ek önlemler alması gerekmektedir (Kamu Denetçiliği Kurumu, 2014: 12). Maden işyerlerinde uygulanacak bu iş sağlığ 1 ve güvenliği yöntemlerinin farklılık göstermesinin en temel nedeni, maden işyerlerinin yapısal olarak bünyesinde birçok tehlike barındırması ve bu nedenle işverenin iş sağlığı ve güvenliğini oluşturmak adına daha çok özen gösterme mecburiyeti altında bulunmasıdır(Selek, 2018: 259).

\section{Yeni İş Sağlığı ve Güvenliği Anlayışı Kapsamında Maden İşyerlerinde Alınması Gereken Koruyucu ve Önleyici Tedbirler}

\section{Risk Değerlendirmesi Yapmak ve Yaptırmak}

Risk değerlendirme anlayışı, AB'nin 12.06.1989 tarihli “İşte Çalışanların Sağlık ve Güvenliklerinin İyileştirilmesine Yönelik Tedbirler Alınmasına İlişkin 89/391 sayılı Direktifi”nde ve ILO’nun 07.06.1985 tarihli “Sağlık Hizmetlerine İlişkin 161 sayılı Sözleşmesi” ile kabul görmüştür (Korkmaz ve Alp, 2017: 161). Bu yeni iş sağlığ1 ve güvenliği anlayışı, iş kazası ve meslek hastalıklarına yönelik önleyici ve koruyucu bir anlayış benimsenmiştir (Akpinar, 2015: 106-108). 
Risk değerlendirmesi anlayışı oluşabilecek muhtemel riskleri hedef almaktadır. Bu doğrultuda risk, teknolojiden kaynaklanan ölüm, yaralanma ya da diğer zarar verici olayların meydana gelme ihtimaline denir. Bu risklerin tespiti, derecelendirilmesi ve kontrol edilmesi için yapılan çalışmalara da risk değerlendirmesi denir(Özdemir, 2017: 645). Risk değerlendirmesi ile işyerinde iş kazasına veya meslek hastalığına yol açabilecek durumlar incelenerek ölçülebilmektedir (Yılmaz, 2013: 56; Özdemir, 2014: 233-235). Ayrıca, risk değerlendirmesi anlayışı çalışanlar yanında, işyerini ve işyeri çevresinde yaşayan insanları da tehlikelere karşı korumayı amaçlamaktadır (İnciroğlu, 2017: 163). Bu şekilde, başta risk değerlendirmesi olmak üzere, çalışan-işveren temsilcisi-iş güvenliği uzmanı-işyeri hekimi-destek elamanı ve diğer ilgili kişilerin birlikte çalışarak işyerinde meydana gelen veya meydana gelmesi muhtemel riskleri bertaraf etmesi amaçlanmıştır (Karakaş, 2014: 102). Bu kapsamda İSGK'nin 4 ile işverenin çalışanları ile ilgili sağlık ve güvenlik önlemleri alması gerektiği ve çalışanlarını korumakla yükümlü olduğu düzenlenmiştir. 4. maddede işverenin yükümlülükleri arasında 1/c bendinde işverenin risk değerlendirme yükümlülüğü düzenlenirken, ayrıca İSK m. 10 hükmünde de risk değerlendirmesi özel olarak düzenlenmiştir. Bu şekilde iş sağlığ ve güvenliği açısından işverene yükümlülük yüklenmiştir (Sevimli, 2013: 130).

Risk değerlendirmesinin amacı tehlikeler büyümeden en baştan tedbir almaktır. $\mathrm{Bu}$ nedenle, işletmeler açısından bir gerekliliktir (Yamakoğlu 2016: 169;Süzek, 2017: 914-915). Özellikle, yer altı ve yer üstü maden işletmelerinde risk değerlendirmesi yöntemi oldukça önem arz etmektedir ve bu nedenle uygulamada s1klıkla görülmektedir (Can vd., 2015: 68; Özdemir, 2014: 233-236). Bunun nedeni, madenlerin sürekli olarak yapılarının değişmesi dolayısıyla mevcut risklerin de sürekli olarak değişmesidir. Ayrıca, madencilik sektöründe karşılaşılan risklerin diğer sektörlere göre farkl1lı göstermesi risklerin periyodik olarak daha s1k incelenmesini zorunlu kılmaktadır (Akpınar, 2015: 187-188;Maden İşletmeleri Grubu 2016: 5).

\section{İşçilere Kişisel Koruyucu Donanım Verilmesi}

Kişisel Koruyucu Donanımların İşyerlerinde Kullanılması Hakkında Yönetmelik (RG: T. 02.07.2013, S.28695) m. 7 hükmü uyarınca, işveren, risk değerlendirmesi yaptırdıktan sonra, uygulanacak iş sağlı̆̆ ve 
güvenliği tedbirlerini ve kullanılması gereken kişisel koruyucu donanımın ne şekilde olacağını belirlemektedir. Yönetmeliğin eki Çizelge 1'de çalışanların kullanmaları gereken kişisel koruyucu donanımların neler olduğu düzenlenmiştir. Buna göre, çalışanların baş koruyucuları, kulak koruyucuları, göz ve yanak koruyucuları, solunum sistemi koruyucuları, gövde ve karın bölgesi koruyucuları, el ve kol koruyucuları, ayak ve bacak koruyucuları, vücut ve cilt koruyucuları şeklinde kullanılacak KKD’ler gösterilmiştir. Tüm sektörlerde olduğu gibi madencilik sektöründe kullanılacak kişisel koruyucu donanımların kullanım şekli, Aile ve Çalışma Sosyal Hizmetler Bakanlığı tarafindan yayınlanan Kişisel Koruyucu Donanımların İşyerlerinde Kullanılması Hakkında Yönetmelik hükümleri ile belirlenmektedir. Bu kapsamda piyasada bulunan tüm KKD’ler CE işaretli olmak zorundadır. CE işareti bulunan ürün azami güvenlik şartlarını taşımaktadır. $\mathrm{Bu}$ nedenle, maden işçilerinin kullanacakları solunum koruyucuları ve diğer koruyucuların bu işareti taşıması gerekmektedir. Solunumu koruyucu donanımlar maden ocaklarında çalışan işçiler açısından oldukça önemlidir (Eser, 2015: 305). Bunun yanında işverenin işçilere koruyucu gözlükler, ayakkabılar, baretler ve diğer KKD araç ve gereçlerini sağlaması gerekmektedir. Bu şekilde işçiler fiziki tehlikelere karşı korunabilecektir. Sağlanan KKD, kaza meydana geldiğinde işçilerin vücut bütünlügünün korunması için büyük önem taşımaktadır (Demirbilek ve Çelik, 2008: 176).İ̧̧verenin, kişisel koruyucu donanımların hangi risklere karşı kullanacağı konusunda çalışanları bilgilendirme yükümlülüğü bulunmaktadır (Özdemir, 2014: 285;Önder ve Günaydın, 2017: 329). Risk ortaya çıktığında da işverenin, işin nitelik ve özeliklerinin gerekli kıldığ 1 , kişisel koruyucu donanımı işçilere vermesi gerekmektedir. Ayrıca, işverenin işçilere tahsis ettiği kişisel koruyuculardan dolayı bir ücret talep etmesi de söz konusu değildir(Karakaş, 2014: 126).

\section{Maden İşyerlerinde İş Güvenliği Uzmanı, İşyeri Hekimi ve Diğer Sağlık Personelinin Görevlendirilmesi}

6552 say1lı Kanunun (RG: T.11.09.2014, S.29116) 16. maddesi ile 6331 sayılı Kanunun 6. maddesi kapsamında, işverenlerin iş güvenliği uzmanı ve işyeri hekimi haricinde diğer sağlık personelini görevlendirmeleri gerektiği hükme bağlanmıştır. Bu hükme göre, "on veya daha fazla çalışanı olan çok tehlikeli sınıfta yer alan işyerlerinde” işverenler iş 
güvenliği uzmanı ve işyeri hekimi dışında diğer sağlık personellerini de görevlendirmektedir. Ancak, bahse konu işyerlerinde çalışan sayısının ondan az olması durumunda, diğer sağlık personeli çalıştırma yükümlülüğü ortadan kalkmaktadır (Gerek, 2014: 11). Bu bağlamda, iş güvenliği uzmanları ve işyeri hekimleri, aldıkları eğitim ve mesleki bilgileri kapsamında işyerlerinde kaza ihtimali oluşturabilecek tehlikelerin tespit edilmesi ve alınması gereken önlemler hakkında görev ifa etmektedirler (Y1lmaz, 2013: 53;Özdemir, 2014: 149-150).

Yargıtay'a göre, işverenin ortak sağlık birimlerinden hizmet alabilmesi için kendisinin görevlendirmiş olduğu işyeri hekimi ve diğer personel ile sağlık birimlerinin nitelikleri bakımından görev tanımının aynı olmaması gerekir. İşverenin öncelikle personelinin bu niteliklere sahip olup olmadığını belirlemesi gerekir. Ondan sonra işveren ortak sağlık birimlerinden bu hizmeti alabilecektir (Y.9.HD, T.02.04.2015, E.2015/3000, K.2015/12939).

\section{Maden İşyerlerinde Daimi Nezaretçi Bulundurulması}

Maden Kanunu m. 31 hükmü, ruhsat sahibine madenlerde gerekli önlemleri alma yükümlülüğü yüklemiştir. Bu şekilde ruhsat sahibi madenlerde iş sağlı̆g 1 ve güvenliği uygulamaları yönünden sorumlu tutmuştur (Yıldız, 2012: 199). Maden İşyerlerinde İş Sağlı̆̆ 1 ve Güvenliği Yönetmeliği’nin “İşverenin Genel Yükümlülükleri” başlıklı 5. maddesinin 2. fikrasında da işyerinde yapılacak her türlü çalışmanın yetkili kişilerin nezareti ve sorumluluğu altında yapılması gerektiği düzenlenmiştir. 6592 sayılı Kanunla yapılan değişik 3213 sayılı Maden Kanunu ile birlikte ruhsat sahipleri, her maden sahasında bir maden mühendisini daimi nezaretçi olarak çalıştırmakla yükümlü tutulmuştur. İşletmede daimi suretle çalıştırılan maden mühendisinin, 4857 sayılı İş Kanunu'nun 81. maddesinde, kanun ve yönetmelikte belirlenen şartları taşıması kaydıyla görevli mühendis veya teknik elemanların iş güvenliği ile üstlendiği görev ve sorumluluğu yerine getireceğine dair düzenlenme bulunmaktaydı. Ancak, 4857 sayılı İş Yasası'nın 81'inci maddesi 6331 sayılı İSGK'nin 37. maddesiyle yürürlükten kaldırılmıştır. Dolayısıyla, yeni iş sağlığı ve güvenliği anlayışı içinde, iş güvenliği uzmanı ile birlikte madenlerde ayrıca bir daimi nezaretçi görevlendirilmesi bir gereklilik halini almıştır (Yeşilyurt, 2015: 112). 


\section{Maden İşçilerine İş Sağlığı ve Güvenliği Eğitimi Verilmesi}

İş sağlığı ve güvenliği açısından eğitim oldukça önemli bir yere sahiptir. Ayrıca iş sağlığı ve güvenliği bilincinin yerleşmesinde de iş sağlığı ve güvenliği alanında verilen eğitimler büyük yarar sağlamaktadır (Eyrenci vd., 2017: 368;Süzek 2017: 909). Zira, çalışanların iş sağlığı ve güvenliği konusundaki bilinçsizlikleri ve yetersizlikleri muhtemel iş kazalarına zemin hazırlamaktadır (Akpınar, 2015: 266). Bu nedenle, verilen eğitimlerin temel amacı, çalışanların iş sağlığı ve güvenliğine yönelik doğru davranış modelleri edinmelerine katk1 sağlamaktır (İnciroğlu, 2017: 155). Eğitimler genellikle, işe girişte, iş sırasında, işyeri veya iş değişikliği gibi durumlarda verilmektedir (Özdemir, 2017: 647). Bu doğrultuda, yer altı madenlerinde çalışan işçilere düzenli eğitimlerin verilmesi ve doğru bilgilendirmelerin yapılması oldukça önemlidir. Örneğin, madende bir yangın çıktığında işçilerin yangınla mücadele edebilecek bilgi donanımına sahip olması vahim sonuçların ortaya çıkmasına büyük ölçüde engel olmaktadır (Ergun, 2007: 27).

Mevzuatımızda, işverenin çalışanlara iş sağlığ ve güvenliği eğitimlerini verilme yükümlülüğü İSGK m. 17 hükmünde düzenlenmiştir. Ancak, madde incelendiğinde, 1. fikrada yer alan düzenleme ile ikinci fikrada yer alan düzenlemenin bazı noktalarda birbirinden ayrıldığı görülmektedir. Buna göre, İSGK m. 17/1 hükmü uyarınca tüm çalışanlara yönelik iş sağlığı ve güvenliği eğitimlerinin verilmesi gerektiği düzenlenmiştir. Bu bağlamda tüm çalışanlara işe girişte ve işin devamı sürecinde iş sağllğ 1 ve güvenliği eğitiminin verilmesi gerektiği anlaşılmaktadır. Ayrıca, işveren bu eğitimleri teknolojik değişimler ve gelişmeler doğrultusunda vermelidir. Teknolojik değişimler sonucu iş ekipmanlarının kullanımı ve diğer yeni gelişmeler hakkında çalışanları bilgilendirmek zorundadır. Ancak, İSGK m. 17/3 hükmünün, Tehlikeli ve Çok Tehlikeli Sınıfta Yer Alan İşlerde Çalıştırılacakların Mesleki Eğitimlerine Dair Yönetmelik hükümleri ile birlikte ele alınması gerekir. Zira, İSGK m.17/3 hükmü tehlikeli ve çok tehlikeli işlerde çalışanlara yönelik verilmesi gereken eğitimlere bir gönderme yapmaktadır. Bir başka ifadeyle, İSGK m. 17/1 hükmü tüm çalışanlara yönelik iş sağlığı ve güvenliği eğitimlerinin işverence verilmesi gerektiğini düzenlerken, İSGK m.17/3 hükmü tehlikeli ve çok tehlikeli işlerde çalışacak işçilere bu alanda ayrıca bir eğitim verilmesini düzenlemiştir. Bu doğrultuda, tehlikeli ve çok tehlikeli işlerde çalışan işçilere İSGK m. 17/1 hükmü uyarınca tüm çalışanlara verilmesi gerekentemel iş sağlığ1 ve güvenliği eğitiminin verilmesi gerekirken, buna ek olarak tehlikeli ve çok 
tehlikeli işlerde çalışanlara ayrıca İSGK m.17/3 hükmü uyarınca da bu alanda eğitim verilmesi gerekmektedir. Ayrıca, İSGK m. 17/3 hükmünden tehlikeli ve çok tehlikeli işlerde çalışmaya uygun olduğunu gösteren mesleki eğitim belgesi bulunmayan kişilerin bu işlerde çalıştırılamayacağı anlaşılmaktadır. Zira, Yönetmelik Ekli Çizelge incelendiğinde de hangi tür işlerde çalışanların mesleki eğitim alması gerektiği düzenlenmiştir. Dolayısıyla, Çizelge ile sayılan işlerde çalışacak kişilerin bu eğitimleri alması zorunludur.

Yargıtay'a göre, işverenin işçisine ilk olarak iş sağlı̆̆ 1 ve güvenliği ile ilgili eğitim vermesi ve mesleki bilgilendirme yapması gerekmektedir. Daha sonrasında işveren işyerinde iş sağlığ 1 ve güvenliği ile ilgili olarak önleyici tedbirleri almalıdır. Ayrıca, işveren işçilere her türlü araç, gereç ve koruyucu donanımı sağlamakla yükümlüdür. Eğer işveren bu aşamaları yerine getirmezse iş kazası olması durumunda zararlandırıcı olaydan bizzat sorumlu olacaktır(YHGK, T.16.06.2004, E.2004/21-365, K.2004/369).

\section{Havalandırma ve Çıkıș Tünelleri}

Türkiye tarafından da onaylanan 176 sayılı ILO Sözleşmesinin 6. maddesinde yer altında bulunan maden sahasının iş sağlığı ve güvenliği açısından birtakım özellikler taşıması gerektiği düzenlenmiştir. Bu kapsamda, Sözleşmede yer altı maden sahasının sağlam bir zemin üzerinde durması ve yer altında havalandırma yerlerinin bulunması gerektiği düzenlenmiştir. Bunun dışında yer altında her maden sahasının yeryüzüne ayrı ayrı çıkışları olan tünelinin açılması gerektiği hususu da hüküm altına alınmıştır. Böylece, 176 sayılı Sözleşmede, işçilerin girip çıktıkları tüm yer altı kazı bölgeleri için havalandırma sistemi oluşturulmasının önemi vurgulanmak istenmiştir (https://www.ilo.org). Bu doğrultuda, havalandırma, kapalı bir ortama mekanik yollarla temiz hava verilmesi işlemidir (Kurt, 2013: 31). Yer altına yeterli miktarda temiz hava verilmesi işlemine ise, "madenlerde havalandırma" adı verilmektedir (Çalışma ve Sosyal Güvenlik Bakanlığ İş̧ Teftiş Kurulu Başkanlığı, 2009: 26). Ayrıca, yer altı maden ocaklarında havalandırma ve yeryüzüne çıkış tünellerinin bulunması iş sağlığı ve güvenliği açısından da oldukça önemlidir. Yer altı işletmecilik faaliyetinin sağlıklı bir şekilde yapılabilmesi açısından ocağın her yerine gerekli temiz havanın verilmesi, içeride bulunan kirli havanın da hızlı ve etkin bir şekilde dışarıya verilmesi önemlidir. Bunun yanında madenin yapısı gereği işletme sırasında oluşan 
zehirli ve patlayıc1 gaz ile toz seviyesinin belirli seviyenin altında tutulması gerekir. Bu şekilde maden ocağında güvenli bir çalışma ortamı sağlanmış olmaktadır (Olgun vd., 2016: 73-74). Bu nedenle, ILO 183 sayılı Tavsiye Kararında, işçilerin erişim sağladığı tüm yer altı maden kazı alanlarının ve diğer alanların, patlama riskinin ortadan kaldırıldığı veya asgariye indirildiği, çalışma koşullarının kullanılan çalışma yöntemi ve işçilere yüklenen fiziksel performans açılarından yeterli düzeyde olduğu bir atmosferin muhafaza edilmesi için uygun şekilde havalandırılması, gaz, toz, radyasyon ve iklim koşullarına ilişkin ulusal standartlara da riayet edilmesi gerektiği yönünde karar vermiştir (Uluslararası Çalışma Örgütü, 2016: 17).

$\mathrm{Bu}$ açıklamalar çerçevesinde, yer altı maden ocaklarında iş sağlığı ve güvenliğinin tesis edilebilmesi için bazı noktalar önem taşımaktadır. $\mathrm{Bu}$ doğrultuda, yer altına girişte ilk faaliyet olarak kazma işlerinin güvenli bir şekilde yapılması gerekmektedir.Daha sonra açılan boşluklar içinde güvenli bir çalışma ortamının oluşması için tahkimatların yapılması gerekmektedir. Ancak, madencilik faaliyetlerinde yerin derinliklerine indikçe havalandırma, su arıtım, nakliyat gibi konular da güvenli bir çalışma ortamının oluşmasında önemli bir rol oynamaktadır (Çalışma ve Sosyal Güvenlik Bakanlığı İş Teftiş Kurulu Başkanlığı, 2009: 11).

\section{Soma Madenlerinde İş Sağlığı ve Güvenliği Uygulamalarına Yönelik İncelemeler}

\section{Genel Olarak Soma Madenleri}

Ülkemizde linyit kömürünün ilk ne zaman kullanıldığı bilinmemekle birlikte 1. Dünya savaşı döneminde (1914-1918) Osmanlı ordusunun yakacak ihtiyacını karşılamak üzere Soma maden yataklarından linyitin çıkartıldığı bilinmektedir (Erbilen ve Şahin, 2015: 114). I. Dünya savaşı sırasındaSoma yataklarında asker çalıştırılarak linyit üretimi başlanmıştır. $\mathrm{Bu}$ dönemde imparatorluğun kömür ihtiyacının artması üzerine başta Soma yatağı olmak üzere Anadolu coğrafyasında birçok yerde linyit ocağ işletmesi kurulmuştur (Kaştan, 2016: 18-19).

Soma yatakları, Cumhuriyet dönemine kadar yabancı sermaye (Alman ve Fransız) tarafından, Cumhuriyet döneminin başında ise büyük ölçüde Türk özel girişimciler tarafından işletilmiştir (Erbilen ve Şahin, 2015: 114). 
$\mathrm{Bu}$ dönemde Soma madenlerinde ve diğer madenlerde devletçilik politikası uygulanmıştır. Devletçilik politikasının da etkisiyle madenler açısından merkezi bir kurum olarak 1935 yılında Etibank kurulmuştur. Bu kurumun kurulmasının ardından özel hukuk kişilerinin elinde bulunan maden işletmeleri devletleştirilmiştir(Öztoprak, 2016:40). Bu doğrultuda, 1927'de Soma, 1928'de Çeltek ve 1938'de Değirmisaz yatakları devletleştirilmiş ve işletme görevi Etibank'a verilmiştir. 1938-1984 yılları arasında toplam $40.000 \mathrm{~km}^{2}{ }^{\prime} \mathrm{lik}$ alanda 117 linyit sahası saptanmış, 2004'e kadar ise, bu alanda bir duraklama yaşanmıştır. 2005'ten 2011 sonuna dek ise, bu alana yeniden bir eğilim başlanmıştır (Erbilen ve Şahin, 2015: 114).14 Haziran 1935 tarihinde yeraltı kaynaklarının araştırılması, incelenmesi ve verimli kullanımını sağlamak amacıyla, Maden Tetkik ve Arama Enstitüsü (MTA)'nün kurulmasıyla birlikte sistemli bir şekilde kömür arama faaliyetleri başlamıştır(http://www.mta.gov.tr). Bu dönemde MTA'nın kurulmasını takiben 1938'de Değirmisaz ve Tunçbilek, 1939'da da Soma modern bir işletme yapısına bürünmüştür(Erbilen ve Şahin, 2015: 112).1.9.1957 yılında TKİ Kurumu Genel Müdürlügünün kurulması ile Tavşanlı' da kurulu GLİ (Garp Linyitleri işletmesi) Müessesesi'nin bir bölgesi olarak faaliyetlerine devam eden işletme, 1.8.1978 tarihinde ELİ Müessesesi olarak tüzel kişilik kazanmış ve Yatağan, Aydın, Soma Bölgeleri ile çalışmalarına başlamıştır. Başlangıçta bu üç bölge ile faaliyetlerini sürdüren Müessese her yıl biraz daha gelişmiş, 15.12.1983 tarihinde Aydın Bölgesinin eski sahiplerine geri verilmesi, Yatağan Bölgesinin de 1.1.1984 tarihinde kurulan GELİ, (Güney Ege Linyitleri işletmesi) Müessesesi’ne bağlanması ile 1984 yılından beri çalışmaları gittikçe büyüyen Soma Bölgesinde yürütmüştür. 1.1.1985 tarihinde Deniş Bölge Müdürlügünün kurulması ile iki bölge, 27.12.1988 tarihinde de Eynez Bölgesinin kuruluşuyla 1989 yılının başından itibaren de üç bölge müdürlüğü ile çalışmalarına devam etmektedir (Atasayar, 1990: 3).

2010'lu yıllar itibarıyla, Türkiye Kömür İşletmeleri Genel Müdürlügü (TKİ) Soma'da hizmet alımı veya rödovans ile özel şirketlere ihaleye çıkmıştır. TKI'nin 2004 y1lında 8,5 milyon ton olan kömür üretimi 2012'de 2,9 milyon tona gerilemiş, aynı dönemde özel firmaların üretimi 58 bin tondan 11,7 milyon tona yükselmiştir(http://www.tki.gov.tr). TKİ, emek yoğun olmayan açık ocak sistemini uygulayarak 2009 ' da 4 bin çalışanla 13 milyon ton üretim yaparken, özel firmalar 2013'te 15 bin çalışanla 12 milyon ton üretim yapmıştır(Türk Sosyal Bilimler Derneği, 2016: 13). Günümüzde, Soma madenlerinin 
yaklaşık olarak, 600 milyon ton kadar bir linyit rezervi bulunmaktadır. Bunun yanında,Soma'dan çıkartılan linyitin oldukça kaliteli olması Soma madenlerinin önemini bir kat daha arttırmıştır(Andaç, 2015: 602).

\section{Soma Madenlerinin İşletilme Şekli ve Üretim Özellikleri}

Soma maden sahasında 21.06.2018-16.07.2918 tarihleri arasında yapmış olduğumuz incelemelerde Soma maden sahasının jeolojik özellikleri, linyit rezervlerinin dağılımı, uygulanan üretim modeli adına önemli bulgular elde edilmiştir. Zira, bu etkenler Soma madenlerinde uygulanan iş sağlığ ve güvenliği politikaları üzerinde de önemli bir rol oynamıştır.

Soma,coğrafi özellikleri bakımından oldukça geniş linyit rezervlerine sahiptir. Buradan çıkartılan linyit ülkemizin enerji ihtiyacının karşılanmasında önemli bir yere sahiptir (TBMM Araştırma Komisyonu).Havza genelinde, kömür madenciliği açısından hem açık ocak madenciliği hem de yer altı madenciliği yapılmaktadır. Bunun yanında, bölgede linyitrezervlerinin çıkartılması açısından özel sektör ve kamu sektörü birlikte faaliyet göstermektedir(http://www.tki.gov.tr).

Soma'da linyit rezervleri Kuzey Doğu-Güney Batı hattı boyunca uzanmaktadır. Maden sahasında linyit yatakları yatay olarak uzanmaktadır. Ayrıca, bölgede metan gazı yüksek değildir. Sahanın sahip olduğu jeolojik özellikler sahada mekanizenin kullanılmasını kolaylaştırmaktadır (TKİ Eğe Linyit İşletmeleri Müessesesi).

Bölgede Kuzey Doğu hattında Kolin Şirketler Grubu bünyesinde faaliyet gösteren Hidro-Gen A.Ş. yer almaktadır. Bölgenin Güney Batı hattında ise, İmbat A.Ş., Soma Kömür İşletmeleri A.Ş., Soma Eynez Yer Altı Kömür İşletmesi-Demir Export bulunmaktadır. Bu şirketler madencilik faaliyetlerini yürüten büyük çaplı işletmelerdir(http://www.tki.gov.tr).Soma maden sahasında bulunan şirketler, TKİ ile yapmış oldukları rödovans sözleşmesi uyarınca kömür çıkartma faaliyetlerinde bulunmaktadır. Devlet adına TKİ bu şirketlerle rödovans sözleşmesini otuz aylık bir süre için yapmıştır ve bu şirketler devlete işletme bedeli ödemektedir. Kolin Şirketler Grubu bünyesinde bulunan Hidro-Gen A.Ş. diğer şirketlere göre daha farklı bir özellik göstermektedir. Şirket, madencilik faaliyetinde bulunmakla birlikte, termik santral inşaatı ile elektrik üretiminde de bulunmaktadır. 
TKİ ile bu şirket arasında yapılan anlaşma uyarınca şirket devlete elektrik üretiminde katkıda bulunmaktadır. Maden sahasında bu şirketlerin yanında devlet bünyesinde rödovans sözleşmesi yapmamış Polyak A.Ş., Polat A.Ş. gibi şirketlerde madencilik faaliyetlerinde bulunmaktadır (TKİ Eğe Linyit İşletmeleri Müessesesi).

Soma'da madenler bölge halkı açısından önemli bir istihdam kapısı yaratmıştır. Bölgede yaşayan insanlar madenlerde istihdam edildiği gibi Soma çevresinde bulunan yerleşim yerlerinden gelen insanlar da madenlerde çalıştırılmaktadır (Türkiye Maden İş Sendikası).

Madencilik mesleği özelliği itibarıyla yüksek istihdam olanakları sağlamaktadır (TBMM Araştırma Komisyonu).Soma bölgesinde de tarım ve hayvancılıkta yaşanan istihdam olanaklarındaki daralma sonucu madenlerde istihdam edilen işçi sayısı önemli sayılara ulaşmıştır (Türkiye Barolar Birliği İnsan Hakları Merkezi, 2014:26).Örneğin, İmbat A.Ş. bünyesinde, 5875 işçi, Soma Kömür İşletmeleri A.Ş. bünyesinde 2693 işçi, Demir Export bünyesinde 1000 işçi, Hidro-Gen A.Ş. bünyesinde termik santralde 3800 işçi ve bu şirketin yapmış olduğu madencilik faaliyetleri dolayısıyla, 292 işçi ek hizmetlerde çalışmaktadır. Bunun yanında, sahada madencilik faaliyetlerine yardımcı atolye, lavvar vb. alanlarda da 1000 işçi çalışmaktadır (TKİ Eğe Linyit İşletmeleri Müessesesi).

Soma madenlerinde maden işçileri günde üç vardiya çalışmaktadır. En çok işçi öğle vardiyasında çalışmaktadır. Soma madenlerinde bir işçi yılda 247 gün çalışmaktadır. Ayrıca, yapılan görevlendirmeler doğrultusunda her işçi belli bir bölgede çalışmaktadır (Türkiye Maden İş Sendikası).

\section{Soma Madenlerinde Uygulanan İş Sağlığı ve Güvenliği Sistemi}

Soma maden sahasinda 21.06.2018-16.07.2918 tarihleri arasında Soma maden sahasında bulunan maden ocaklarında uygulanan iş sağlığı ve güvenliği yöntemleri üzerine bir araştırma yapılmıştır. Bu doğrultuda, iş sağlı̆̆ ve güvenliği uygulamalarında Soma maden faciası sonrasında bir değişim olup olmadığı ele alınmıştır. Bu bağlamda, Soma maden faciası sonrası dönemde uygulanan iş sağlığ 1 ve güvenliği politikalarını daha iyi tahlil edebilmek adına Soma maden faciası öncesi dönemde uygulanan iş sağlığı ve güvenliği politikalarını ele almak isabetli olacaktır. 


\section{Soma Maden Faciası Öncesi Dönem}

Ülkemizde her yıl birçok sektörde vahim sonuçlara yol açan iş kazaları yaşanmaktadır. Özellikle ülkemizde iş kazalarının yaşanması açısından maden ocakları kötü bir sicile sahiptir. Bu doğrultuda,1991-2008 yılları arasında madenlerde yaşanan kazalar ve meslek hastalıkları sonucu 2554 emekçi hayatını kaybetmiştir(http://www.sgk.gov.tr). Daha sonraki süreçte demadenlerde görülen bu olumsuz tablo artan bir seyirde devam etmiştir. Örneğin, 2012 yılında ülkemizde tüm sektörleriçinde en çok iş kazası 8.828 iş kazası ile kömür ve linyit çıkartılan işyerlerinde yaşanmıştır (TMMOB, 2018: 50).2013 yılında da maden ocakları en çok iş kazasının yaşandığı sektörler içinde yer almıştır. 2014 yılına gelindiğinde ise, Soma maden faciasında 301 iş̧̧inin acı bir şekilde hayatını kaybetmesi ile birliktesadece ilk beş aylık periyotta dahi 700 üzerinde ölümle sonuçlanan iş kazası vakası yaşanmıştır. Soma maden faciasının yaşanması üzerine gözler maden ocaklarına çevrilmiştir(Türkiye Barolar Birliği İnsan Hakları Merkezi 2014: 11).Ayrıca, Soma maden faciasının yaşanması ile birlikte kazanın yaşanmasında teknik nedenlerin etki edip etmediği, ihmallerin olup olmadığı, iş sağlığ 1 ve güvenliği organizasyonunun yapılıp yapılmadığ 1 , işverenin iş sağlığ1 ve güvenliğini sağlama yükümlülüğüne uyup uymadığı, İSGK bağlamında mevzuattan kaynaklanan önleyici tedbirlerin alınıp alınmadığı, rödovans ve uygulanan kömür politikaları tartışma konusu olmuştur

Kömür Politikaları. Kömür, elektrik enerjisi üretiminde kullanılan temel enerji kaynaklarının başında gelmektedir. Bu da daha çok kömür üretimini tetiklemektedir (http://www.emo.org.tr/).Bu nedenle, ülkemizde madenlerde yaşanan iş kazalarının arka planında uygulanan kömür politikaları yatmaktadır. Zira, maden ocaklarından elde edilen kömürün bir enerji kaynağı olması ve özellikle elektrik üretiminde kullanılması madenlerde uygulanan bazı yanlış politikaların görmezden gelinmesine neden olmuştur. Soma maden faciasının yaşanmasında da uygulanan kömür politikaları etkili olmuştur. Bu nedenle, özellikle Soma madenlerinde rödovans uygulamaları artmış ve maalesef denetimler de yeterince yapılmamıştır (Türkiye Barolar Birliği İnsan Hakları Merkezi 2014: 36). Dolayısıyla, yeterince denetlenmemiş rödovanslı maden sahalarındaiş sağlığı ve güvenliği açısından da gerekli önlemlerin alınmasını beklemek söz konusu değildir(Topaloğlu 2014: 64-66).

Teknik Eksiklikler ve Yetersizlikler. 13 Mayıs 2014 günü saat 15.10 sularında ruhsat hakkı Türkiye Kömür İşletmeleri'ne (TKİ) ait olup Soma 
Kömür İşletmeleri A.Ş. tarafindan işletilmekte olan Soma Eynez/Karanlıkdere Kömür Ocağında meydana gelen Türkiye'nin tarihine kara bir leke olarak geçen Soma maden faciasında 301 kişi yaşamını yitirmiş, 90 kadar kişi de yaralanmıştır.(Türkiye Barolar Birliği İnsan Hakları Merkezi 2014: 11-13). İlk bulgulara göre, madende ana yolları birleştiren üçgensel bir bölge olan kavşakta yangın çıkması sonucu, yangın giderek büyümüş ve 301 madenci hayatını kaybetmiştir (TBMM Araştırma Komisyonu). Teknik ifadeyle, ana taşıma galerisinde kömürün hava kütlesinde bulunan oksijen ile tepkimeye girmesi (oksidasyon) üzerine ortamda bir "kızışma” olmuş ve kızışma sonucu karbonmonoksit gazı ve ısı açığa çıkarak ortam yanmaya başlamıştır (Türkiye Barolar Birliği İnsan Hakları Merkezi 2014: 19). Bunun yanında, kaza yerinde yapılan incelemelerde ocak havasına karışmış 48 adet karbonmonoksit, metan ve diğer zehirli gazların bulunduğu ve bu gazların yanmayı hızlandırabileceği tespit edilmiştir (TMMOB Türkiye Maden Mühendisleri Odası, 2014: 28-29). $\mathrm{Bu}$ nedenlerle Soma maden faciasının yaşanmasında madende teknik açıdan iş sağlığ ve güvenliğine uygun ocak içi dizaynının yapılmadığı anlaşılmıştır. Dolayısıyla bu sebeplerin etkisiyle toplu işçi ölümleri kaçınılmaz hale gelmiştir(Gerek, 2015: 26-27).

Kişisel Koruyucu Donanım ve Havalandırma Eksiklikleri. Soma maden kazasının yaşandığı dönemde madende iş sağlığı ve güvenliğini olumsuz etkileyecek birtakım aksaklıklar da bulunmaktadır. Bu doğruluda madende çalışan işçilere sağlanan kişisel koruyucu donanımlar eskidir ve bu donanımlar işçileri koruyabilecek nitelikte değildir. Ayrıca, işçilere düzenli olarak kişisel koruyucu donanım sağlanmamaklabirlikte, mevcut kişisel koruyucu donanımların da düzenli olarak bakımı yapılmamıştır(TMMOB Türkiye Maden Mühendisleri Odası, 2014: 30-31).Zira, kişisel koruyucu donanımların işçilere tahsis edilmesinin temel nedeni, kaza anında çalışanların vücut bütünlüğünü korumaktır. Bu doğrultuda, çalışma ortamına uygun kişisel koruyucu donanımın işçilere tahsis edilmesi, çalışan sağlığı açısından oldukça önemlidir(Demirbilek ve Çelik, 2008: 176). Bu nedenle, işverenin muhtemel kaza risklerini gözeterek işçilere kişisel koruyucu donanım tahsis etmesi gerekmektedir (Karakaş, 2014: 126). Dolayısıyla, Soma maden faciasında ortaya çıkan bu içler acısı fotoğraf düşünüldüğünde, işverenin kişisel koruyucu donanımları gerektiği şekilde sağlamadığı görülmektedir. Bunun yanında o dönemde, Soma madenlerinde havalandırma sisteminde de bazı eksiklikler bulunmaktadır. Ocakta ana havalandırma sisteminin yetersiz olması nedeniyle çok sayıda yardımcı havalandırma olarak vantilatör kullanılmıştır. 
Ayrıca, bu şekilde çok sayıda vantilatörün kullanılmasının yangına yakın ve metan içeren damarlarda Soma maden faciasında bu olumsuz tablonun ortaya çıkmasına da bir etkisinin olabileceği kayıtlara geçmiştir(TMMOB Türkiye Maden Mühendisleri Odas1, 2014: 28-29).

ISG Organizasyonunun Oluşturulamaması. Soma maden faciasında 301 madencinin hayatını kaybetmesine yol açan bu vahim sonucun ortaya çıkmasında ihmal olup olmadığı sorusu zihinlerikurcalamıştır. Zira, Soma maden faciasının yaşanmasında ocak içinde iş sağlığı ve güvenliğinin sağlanamaması, risklerin önceden tespit edilememesi, ocak koşullarının yeterince denetlenmemesi, acil durum yönetiminin yapılamaması, yangının çıkmasından sonra alınan yanlış kararlar ve yanlış uygulamalar etkili olmuştur. $\mathrm{Bu}$ nedenledir ki, şüphesiz Soma maden faciasının yaşanmasında ve üzücü sonuçların ortaya çıkmasında birbirini etkileyen olaylar zincirive ihmaller silsilesi bulunmaktadır (Düzgün, 2016: 6).Bu nedenle, Soma madenlerinde bu denlibüyük bir yangının ve ölümlerin olması Soma madenlerinde iş sağlığ1 ve güvenliği organizasyonunun yetersiz hatta yok denecek seviyede olduğunu gözler önüne sermiştir (TBMM Araştırma Komisyonu). Zira o dönemde,Soma madenlerinde iş sağlığı ve güvenliğiorganizasyonuaçısındanönemli sorunlar bulunmaktadır. Örneğin, işverenin işçileriüretime zorlaması, işverenin gerekli yatırımları yapmaması, izlenen üretim sistemi, ocak tasarımı ve işletmesel problemler öne çıkmaktadır. Ayrıca, bu olumsuzluklar Soma maden faciasının yaşanmasına da zemin hazırlamıştır(Andaç, 2015: 602).

Uygulanan Yanlış ISG Politikaları. Soma maden faciasının yaşanmasında temel etkenlerden biri de uygulanan iş sağlığı ve güvenliği politikaları olmuştur. Soma madenlerinde o dönemde genel olarak çalışma ortamında iş sağlığı ve güvenliği gözetilmemekte ve işçilerin talepleri genellikle sonuçsuz kalmaktadır (Türkiye Barolar Birliği, 2014: 29-30).Zira, iş sağlı̆̆ı ve güvenliği sisteminin oluşturulması işveren adına bir maliyet kalemi yaratmaktadır. Bir başka ifadeyle işveren ek maliyet oluşturacağ1 düşüncesiyle iş sağlı̆̆1 ve güvenliği açısından önleyici mekanizmalarıtam anlamıyla oluşturmaktan imtina etmiştir. $\mathrm{Bu}$ da kaza yaşanmasını kaçınılmaz hale getirmiştir. Ancak, önlemek ödemekten daha ucuzdur anlayışı benimsenseydi bu kaza yaşanmayabilirdi (Tezel ve Kurt, 2009: 99).

Şu bir gerçektir ki, Soma maden faciasının yaşanmasında büyük ihmal bulunmaktadır (Düzgün, 2016: 7).Zira,Soma maden faciası öncesi dönemde 
ve Soma maden faciasına giden süreçte Soma madenlerinde iş sağlı̆̆ ve güvenliği organizasyonunda birçok eksiklik bulunmaktadır. Özellikle, madenlerde iş sağlığı ve güvenliği sistemi oluşturulamamış ve iş sağlığı ve güvenliğine yönelik gerekli önlemler alınmamıştır. Her şeyden önce, İSGK ile benimsenen önleyici anlayış Soma madenlerinde maalesef uygulanmamıştır. Bir başka ifadeyle, tehlikenin gelmesi beklenmeden en baştan tedbir alma anlayışı benimsenmemiştir.

Soma madenlerinde görülen bir diğer sorunda, işverenlerin düşük maliyet politikası güderek niteliksiz işgücüne yönelmesi ve bu nedenle iş sağlığ ve güvenliği sisteminin tam olarak oluşturulamamasıdır(Türkiye Barolar Birliği İnsan Hakları Merkezi, 2014: 30-31). Zira o dönemde, Soma madenlerinde içselleştirilmiş bir iş sağlığı ve güvenliği kültürü ve iş sağlığı ve güvenliği anlayışı bulunmamaktadır (Düzgün, 2016: 9).Bu nedenle, Soma maden faciasının yaşanmasında yer altında bilgisiz ve yetersiz kişilerin çalışması ve bunun sonucu olarak oluşan kaos ve ölümcül risk ortamı etkili olmuştur. Ancak Soma maden faciasının yaşanmasında, risk değerlendirmesinin ve yönetim sisteminin zayıf olması, eğitimsizlik, madenciliği bilmeyen arama kurtarma ekiplerinden kaynakl1 sorunlar, erken uyarı sisteminin olmaması ya da yetersiz olması, geri hizmetlerin eksikliği, gibi sorunlar da etkili olmuştur (Andaç, 2015: 602).

Denetim Zaafi. Madencilik, bünyesinde birçok tehlike ve riskleri barındıran bir sektördür. Bu nedenle, madenlerin düzenli olarak denetlenmesi son derece önemlidir. Aksi halde, madenlerde iş kazalarının yaşanması kaçınılmaz hale gelmektedir (TBMM Araştırma Komisyonu). Bu nedenle,Soma maden faciasının yaşanası ile birlikte, Soma madenlerinin iş sağlı̆̆ı ve güvenliği açısındandüzenli ve gerekli şekilde denetlenmediği gün yüzüne çıkmıştır. Bu doğrultuda, Maden İşletmeleri Genel Müdürlüğü (MİGEM) ve Aile ve Çalışma Sosyal Hizmetler Bakanlığı eski adıyla Çalışma ve Sosyal Güvenlik Bakanlığına bağlı İş Teftiş Kurulu (İTK) tarafından Soma madenleri düzenli olarak denetlenmiş ve gerekli uyarılar yapılmış olsaydı bu vahim kaza yaşanmayacaktı (Düzgün, 2016: 8-9).Bunun yanında, Soma Kömür İşletmeleri ile Devlet adına rödovans sözleşmesi yapmış olan TKİ de madenlerin denetlenmesi konusunda üzerine düşeni yapmamıştır. Dolayısıyla, TKİ kontrol teşkilatı, iş güvenliği uzmanları, teknik nezaretçiler, MİGEM personeli ve iş müfettişleri Soma madenlerinde bir denetim zaafı göstermiş̧lerdir (TMMOB Türkiye Maden Mühendisleri Odası, 2014: 31). 
Rödovans Uygulamasının Olumsuz Etkileri. Soma maden faciası yaşanmadan önce maden sahasında görülen rödovans uygulamaları da iş sağlığı ve güvenliği sisteminin tam anlamıyla oluşmasına mani olmuştur. Zira, rödovans sözleşmesi ile ruhsat sahibi, madeni işletmek isteyen rödovansçıya maden işletme iznini devretmektedir(Baycık, 2011: 1895). Rödovansçı da bunun karşılığında, rödovans bedeli denen bir bedeli ruhsat sahibine vermektedir. $\mathrm{Bu}$ nedenle, rödovans maden ruhsat kârının hak sahibi tarafından madeni işletmek isteyen kişilere belli bir süre ile sınırlı olarak tahsisidir (Erekmekçi ve Süleymanoğlu, 2016: 137;Öztoprak, 2016: 109). Tahsis dolayısıyla ton başına elde edilen hasılat ise, kira geliri olarak adlandırılmaktadır (Çankaya 2014: 4-5). Sözleşme taraflara bazı yükümlülükler de yüklemektedir. Bu kapsamda ruhsat sahibinin, maden sahasında rödovansçının madeni işletebilmesi için gerekli koşulları sağlaması gerekmektedir. Rödovansçının da maden sahasını taahhüt ettiği şekilde işletmesi gerekmektedir (Topaloğlu 2001: 251). Ancak, Soma maden faciasının yaşanmasında temel etkenlerden biri de rödovans uygulamaları olmuştur. Zira, rödovens sözleşmesi ile ruhsat sahibi tarafından işletme hakkının devri sırasında iş sağlığı ve güvenliği açısından gerekli incelemeler ve denetimler yapılmamıştır. Bir başka ifadeyle, işletme hakkı devredilmiş ancak, iş sağlığ ve güvenliği ikinci plana atılmıştır(Topalığlu 2014: 52). Dolayısıyla, rödovans sözleşmesi, iş sağlığ 1 ve güvenliği yükümlülüklerinden bir kaçış yolu olarak görülmüştür. Soma maden faciası öncesi dönemde bu şekilde iş sağlığı ve güvenliği uygulamaları önemsenmeden rödovans sözleşmeleri yapılmıştır. Ayrıca, rödovans uygulaması ile işçiler iş sağlığı ve güvenliği talepleri açısından ruhsat sahibine mi yoksa rödovansçıya mı gideceklerini bilememiş ve işçilerin iş sağlığı ve güvenliğine dönük talepleri çoğu zaman sonuçsuz kalmıştır. Dolayısıyla, rödovans sözleşmesi ile maden ruhsat sahası parsellere bölünmüş ve bu durum birtakım olumsuzlukları da beraberinde getirmiştir (Çankaya 2014: 6-7).Bir başka ifadeyle rödovans sözleşmeleri yapılırken gerekli denetlemeler ve incelemeler yapılmamıştır(Topaloğlu 2001: 249). $\mathrm{Bu}$ nedenle, Soma maden faciasını yaşanması üzerine rödovans sözleşmeleri verödovans sözleşmelerinin niteliği daha çok sorgulanmaya başlanmıştır. Zira,rödovans sözleşmesinde ruhsat sahibinin maden işletme hakkını neden rödovansçıya devretme ihtiyacı duyduğu, ekonomik sebeplerle mi bu yola başvurduğu ve bu nedenle iş sağlığ ve güvenliğinin ikinci plana atabileceği tartışma konusu olmuştur (Baycık, 2011: 1895-1898).Ayrıca, Soma maden 
faciasının da Türkiye Kömür İşletmeleri A.Ş. tarafından işletilen rödovanslı maden sahasında meydana gelmesi de rödovans uygulamasının daha fazla sorgulanmasına yol açmıştır(Topaloğlu, 2014: 64).

Kanaatimizce Soma maden faciasının yaşanmasında rol oynayan yanlış uygulamalardan biri de Soma maden sahasında görülen rödovans uygulamaları olmuştur. Rödovans uygulamaları ile maden sahaları bölünmektedir ve bu da iş kazalarına davetiye çıkartmaktadır. Ayrıca, rödovans sözleşmeleri yapılırken genellikle iş sağlığı ve güvenliği açısından gerekli denetimlerin yapılmaması da iş kazalarını arttırmaktadır. Bu nedenledir ki, ileride Soma benzeri büyük faciaların yaşanmaması adına madencilik sektöründe rödovans uygulamalarının kaldırılması sektörün selameti açısından oldukça fayda sağlayacaktır. Rödovansa alternatif olarak merkezi bir sistemin kurulması ve ortak standartlar belirlenerek farklı uygulamaların kaldırılması Soma benzeri kazaların yaşanmasının önüne geçecektir.

İşverenin ISGK'dan Doğan Yükümlülü̈klerine Uymamast. Soma maden faciasının yaşanmasında işverenin ve işverene bağlı kişilerin İSGK bağlamında yükümlülüklerini yerine getirmemesi ve iş sağlı̆̆ 1 ve güvenliğine yeteri kadar önem verilmemesi önemli rol oynamıştır. Zira, İSGKm.4 ve m.10 ile işverene iş sağlığı ve güvenliğini sağlama, iş sağlığı ve güvenliğini tesis etme ve bu paralelde risk değerlendirmesi yapma veya yaptırma yükümlülüğü yüklenmiştir. Ancak, Soma maden faciası öncesi dönemde işveren iş sağlığı ve güvenliğini sağlama yükümlülüklerini yerine getirmemekle birlikte, risk değerlendirmesini de düzenli olarak yapmamış veya yaptırmamıştı. Eğer, işveren periyodik olarak risk değerlendirmesi yaptırmış olsaydı ve belirlenen riskler düzenli olarak kayıt altına alınmış olsaydı bu denli büyük bir kaza kuvvetle muhtemel yaşanmayacaktı. Dolayısıyla, işverenin düzenli olarak risk değerlendirmesi yaptırmadığı ve tehlikeleri önlemek adına bir çabasının da bulunmadığı anlaşılmıştır. $\mathrm{Bu}$ doğrultuda, işveren İSGKm.5 ve m.15 hükmü kapsamında da yükümlülüklerini yerine getirmemiştir. Bunun yanında, işveren iş sağlığı ve güvenliğini oluşturmak adına madende düzenli denetimler yapmamış, iş sağlı̆̆ ve güvenliği sistemini oluşturmamış, gerekli sağlık personelini de görevlendirmemiştir. Bunun yanında işveren işçilere gerekli KKD ve diğer araç ve gereçleri düzenli olarak temin etmemiştir. Ayrıca, işçilere verilen KKDler genellikle eski ve bazıları da bozuktur, Buna ek olarak, işçilere sağlanan diğer araç ve gereçlerin de düzenli olarak bakımı yapılmamıştır (TMMOB Türkiye Maden Mühendisleri Odası, 2014: 30-31). 
İlaveten, madende havalandırma ve tahliye sistemi tam olarak oluşturulamamış ve bu sistemler etkin kullanılmamıştır. Madenin tahliyesi gerektiğinde, hızlı ve etkin bir tahliye sistemi kurulmamıştır. Bunun yanında, madende acil durum ilk müdahale ekipleri oluşturulmamıştır. Dolayısıyla, madende bir yangın ya da patlama olduğunda acil müdahale edebilecek tam teşekküllü bir ekip mevcut değildir. Bunların dışında, madende ilerleme sağlıklı ve güvenli bir şekilde olmamış ve tahkimatlar yeterince güçlü yapılmamıştır. İşçilere düzenli olarak iş sağlığı ve güvenliği eğitimleri de verilmemiştir. Bu nedenle risk anında işçiler tam olarak ne yapacaklarını öngörememiştir. Ayrıca, madende hava basıncını, gaz derecesini tam olarak ölçen ve derecelendiren bir sistem tesis edilmemiştir. Oluşturulan sistemde tam olarak çalışmamıştır. Buna ek olarak, madende bulunan kömür çıkarma işinde kullanılan makineler düzenli olarak bakım altına alınmamıştır. Dolayısıyla Soma madenlerinde iş sağlığı ve güvenliğini olumsuz etkileyen birçok etken bu dehşetin yaşanmasına zemin hazırlamıştır.

\section{Soma Maden Faciası Sonrası Dönem}

Amaç. Soma maden sahasında 21.06.2018-16.07.2918 tarihleri arasında yaptığımız incelemelerde Soma maden faciası öncesi dönem ile Soma maden faciası sonrası dönemde iş sağlı̆̆1 ve güvenliği uygulamalarına yönelik bir karşılaştırma yapılmıştır. Bu doğrultuda, Soma maden faciası sonrası dönemde iş sağlığ ve güvenliği uygulamalarında bir değişiklik olup olmadığ1 sorusuna cevap aranmıştır.

Yöntem. Bu çalışmada Soma madenlerinde uygulanan iş sağlığı ve güvenliği yöntemlerini anlayabilmek adına Soma maden sahasında bulunan maden ocaklarında incelemeler ve gözlemler yapılmıştır. Ayrıca, TKİ Ege Linyit İşletmeleri Müessesesi ve Türkiye Maden İş Sendikasından bazı bilgi ve belgeler temin edilmiştir. Bunun yanında, bölgede görev yapan iş sağlığ1 ve güvenliği alanında yönetici pozisyonunda olan 20 yetkili ile mülakat görüşmeleri yapılmıştır. Görüşmeler sırasında bazı yetkililer kişisel bilgilerinin saklı tutulmasını talep etmiştir. Bu nedenle, görüşme yapılan bazı kişilerin demografik özelliklerine çalışmada yer verilmemiştir.

\section{Bulgular}

İs sağlığı ve güvenliği uygulamaları. Genel olarak Soma madenlerinde yapılan incelemelerde iş sağlığg ve güvenliği anlayışında bir değişiklik olduğu 
saptanmıştır. Son yıllarda madencilik alanında yaşanan gelişmelerle birlikte, insan gücünün yanında gelişmiş makineler Soma maden faciası öncesi döneme kıyasla daha yaygın bölgede kullanılmaya başlanmıştır (TKİ Eğe Linyit İşletmeleri Müessesesi).

Soma madenlerinde Soma maden faciası sonrası dönemde büyük çapta olmasa da küçük çapta maden kazaları yaşanmaya devam etmektedir. $\mathrm{Bu}$ kazaların yaşanmasında madenlerde kullanılan teknoloji ürünü donanımdan kaynaklı sorunlar etkili olmaktadır. Soma maden sahasında madenlerde çok fazla makine kullanılması dolayısıyla işçilerin çok dikkatli olması gerekmektedir. Madenlerde çalışan işçilerin dikkatsiz hareket etmesi durumunda iş kazası olma riski artmaktadır.Bu doğrultuda, iş sağlığı ve güvenliği uygulamaları açısından Türkiye Maden İş Sendikası yetkilileri bu konuda önemli bazı hususlara işaret etmiştir.

“...Sendika olarak asıl amacımı maden işçilerinin să̆ selim evlerine ulaşmalarını sağlamaktır. Sendika kapsamında işçilere eğitimler vermekteyiz. Yapmış olduğumuz çalışmalarla madenlerde iş kazalarını en aza indirmek istiyoruz. Madende iş kazalarının önlenmesi için emniyet çok önemlidir. Maden ocaklarında gerekli ekipmanlar bulunduğu sürece, iş güvenliğine uyulduğu sürece iş kazalarının oranı daha da azalacaktır. Ayrıca, iş kazalarının azalması için işçinin morali, uyku düzeni, açlık tokluk durumu beslenme düzeni ve dikkatli olması işine konsantre olması çok önemlidir. Madende çalışan işçilerde bu hususlara dikkat edilmektedir..." (Türkiye Maden İşS Sendikası 1 Nolu Ege Şubesi Yetkilisi, 2018).

“....Soma madenciliğinde makineleşmenin avantajlı ve dezavantajlı birtakım sonuçları olmuştur. Makineleşme ile işçi hata yapmadığı sürece madende doğal kaza olma olasılığg çok düşmüştür. Makineleşme ile birlikte madende göçük olma riski çok azalmıştır. Ancak madenlerde kullanılan makinelerin çok büyük olması dolayısıyla işçinin çok dikkatli olması gerekmektedir. $\mathrm{Bu}$ nedenle işçinin ufak bir dikkatsizliğinde uzuv kayıpları olması veya ölümle sonuçlanan iş kazalarının olma riski yüksektir. Kaza olma riski düşük ama kaza olması durumunda büyük kayıplar olmaktadır.." (Türkiye Maden İşçileri Sendikası Ege Bölgesi Şubesi Yetkilisi, 2018). 
Havalandırma, ocak havası ve koruyucu donanımlar. Soma madenlerinde iş sağlığı ve güvenliğinin sağlanması adına havalandırma sistemleri yenilenmiştir. Bu bağlamda, madenlerde tali havalandırma sisteminden ziyade ana havalandırma sistemleri kurulmaya başlamıştır. Bununyanında, basınçlı hava kompresörleri de madenlere girmiştir. Bu şekilde madenlerde çalışan işçilerin yanıcı ve patlayıcı gaz ortamlarına karşı korunması amaçlanmaktadır. $\mathrm{Bu}$ makineler işçilerin sağlığı ve güvenliği açısından oldukça önem taşımaktadır. Bu şekilde madenlerde basınçlı hava ihtiyacı karşılanmaktadır. Ancak, işçilerin güvenliğinin sağlanması açısından kompresörlerin düzenli olarak bakımının yapılması gerekmektedir. $\mathrm{Bu}$ konuda, Soma Kömür İşletmeleri A. Ş. bünyesinde çalışan bir yetkiligörüşlerini şu şekilde ifade etmiştir.

“..2016 yılında kompresörlerin arıalanması dolayısıyla 6 işçinin rahatsılanmıştı. Ancak daha sonra böyle bir arıza yaşanmadı. Madende yaşanan bu arıadan sonra kompresörler daha sık denetlenmeye başladı..” (İş Sağhlğ ve Güvenliği Uzmanı, 2018)

Soma maden sahasında yapılan incelemelerde yer altı maden ocaklarında su fiskiyelerinin kurulduğu gözlemlenmiştir. Su fiskiyeleri ile kömür tozlarının havada dolaşması önlenmeye çalışılmaktadır. Fiskiyeler bantlar boyunca kurulduğu gibi yer altı maden ocağında ana yollar üzerinde de kurulmuştur. Bu şekilde işçilerin akciğer hastalıklarına yakalanması önlenmek istenmektedir. Ancak, işçilerin akciğer hastalıklarına yakalanması tamamen engellenememiştir. İşçilerin akciğer hastalıklarına yakalanmaması açısından koruyucu donanımlar da sağlanmakla birlikte, Soma maden sahasında çok geniş kömür yataklarının bulunması ve kömür kesme, nakliyat ve paketleme sirkulasyonunun devam etmesi nedeniyle işçiler ister istemez kömür tozlarından olumsuz etkilenmektedir.

Soma maden sahasında faaliyet gösteren şirketler müfettişler tarafindan düzenli olarak denetlenmektedir. Bu denetimler sırasında şirketlerin işçilere koruyucu donanımı eksiksiz olarak sağlayıp sağlamadığı da denetlenmektedir. Bu kapsamda çizme, baret, maske, gözlük, kulaklık ile ilgili incelemeler yapılmaktadır. Örneğin çizmelerin ucunda bir demir aksamının bulunması gerekmektedir. Çizmenin ucunda demir aksam olmaması durumunda işçinin ayağına kömür parçası düşmesi durumunda işçilerin zarar görme tehlikesi bulunmaktadır. Soma maden sahasında çalışan yetkililer bu konuda bazı önemli noktalara değinmiştir. 
“....iş̧̧ilerin koruyucu donanım kullanmalarına özen göstermekteyiz. Iş̧̧ilere çizme ve elbisenin üç ayda bir verilmektedir ancak işçinin çizmesinin yada elbisesinin kaybolması durumunda hemen işçilere bu ekipmanlar sağlanmaktadır..." (Vardiya Amiri, 2018)

“...Soma maden faciası yaşanmadan önceki dönemde iş̧̧ilere koruyucu donanımın bu sıklıkla verilmemekteydi. Isşçiler elbisesini kaybettiğinde ya da elbiseleri giyilemeyecek durumda olduğunda kendileri dışarıdan satın almak zorunda kalmaktaydı...." (Daimi Nezaretçi, 2018)

“...Soma maden kazası sonrasında işçilere sağlanan koruyucu ekipman açısından çok dikkatli davranılmaya başlanmıştır. Maalesef 2014 öncesinde bu iş bu kadar önemsenmemekteydi.." (Jeoloji Mühendisi, 2018)

“..Madende çalışırken koruyucu donanımın takılması olmazsa olmaz bir şey. Madende çalışırken maske takmayan birçok arkadaşımı akciğer hastalığına yakalandı. Maden ocaklarında tozun kalkmaması için fiskiyeler ve su bölümleri olsa da maske çalışırken mutlaka takılmalıdır." (İşveren, 2018)

Soma madenlerinde koruyucu donanım olarak yer altında çalışan maden işçileri için önemli bir diğer araç da korsedir.Buna göre, işçinin beline korse takması da gerekmektedir. İşçi bel korsesi takmaması durumunda bel sakatlıklarl olabilmektedir.

$\mathrm{Bu}$ koruyucu donanımlar madenlerde çalışan işçilerin sağlığı açısından çok önemlidir. Ancak, Soma maden faciası yaşanmadan önceki süreçte koruyucu donanımlar düzenli kontrol edilmemiştir ve işçilerin korunaklı çalışmasına gereken ehemmiyet verilmemiştir. Soma maden faciası sonrası dönemde koruyucu donanımların düzenli şekilde çalışanlara verilmesine ve koruyucuların kontrolüne daha fazla özen gösterilmiştir. Soma madenlerinde çalışan yetkililer bu konuda bazı önemli hususlara işaret etmiştir.

“....IŞ kazası ve meslek hastalıklarının önlenmesi açısından maden ocağında çalışan işçilerin diğer koruyucuların yanında, koruyucu kulaklık takması da gerekir. Kulaklık takmaması durumunda işitme kaybının olması mümkündür...” (İ̧s Sağlı̆̆ı ve Güvenliği Uzmanı, 2018) 
“...Madenlerde kullanılan araç, gereç ve makinelerdeki arızalar, arıza üzerine etkin ve erken müdahale yapılamamast, arızalanan makinenin veya araç ve gerecin yedeğinin her zaman temin edilememesi gibi nedenler kazalara neden olmaktadır. Bu kazaların yaşanmasında işverenlerin de hatası bulunmaktadır. Zira, madende kullanilan araç, gereç ve makinelerin düzenli olarak bakımının yapılmaması, teknik eleman yetersizliği ya da teknik elemanının gerekli bilgi donanımına sahip olmaması, makinelerin, araç ve gereçlerin bozulması durumunda uygulanacak yöntemin önceden kesin ve sistematik olarak belirlenmemesi de etkili olmaktadır." (Maden Mühendisi, 2018)

Acilmüdahaleyangınla mücadeleveilkyardım. Somamadenlerindeyapılan incelemelerde, acil mücadele, yangınla mücadele, ve ilk yardım açısından birtakım uygulamaların hayata geçirilmeye çalışıldığı gözlemlenmiştir. Özellikle, Soma maden faciası sırasında acil müdahale, yangınla mücadele ve ilk yardım sisteminin çok yetersiz kalmıştır. Soma maden faciası sonrası dönemde bu alanda yeni bir yapılanmaya gidilmiştir. Zira, gerekli tedbirler alınmazsa linyit kömürünün hemen tutuşabilmesi nedeniyle madende tekrar yangın çıkması içten bile değildir. Bu konuda, Soma madenlerinde görev yapan yetkililer,

“...Soma maden faciast sonrası Soma maden sahasinda büyük çapta bir maden kazası yaşanmamıştır. Küçük çaplı kaza yaşanması durumunda da hemen müdahale edilmeye çalışllmaktadır. Özellikle Soma maden faciası sonrası gözlerin buraya çevrilmesi işverenleri daha temkinli ve dikkatli olmaya itmiştir. Bu nedenle Soma maden sahasında işverenler, bir iş kazası sonucu vahim sonuçların oluşmasını önlemek için, acil müdahale ekipleri ve ilk yardım ekipleri kurmanın önemini anlamıştır. Ancak Soma maden sahasında büyük çapta olmasa da halen iş kazası ve meslek hastalıkları yaşanmaya devam etmektedir. Bu durumda da oluşturulan ekiplerin olay mahalline hemen intikali ve etkin müdahale etmeye çalışmaktadır..." (Jeoloji Mühendisi, 2018)

“...Soma maden sahasında oluşturulan ekiplerle iş kazası olması halinde daha büyük kayıpların yaşanmaması adına müdahaleler yapılmaktadır." (Maden Mühendisi, 2018) 
“..Yer altı madenciliği açısından iş să̆llğg ve güvenliği tedbirlerinin uygulanması hayati önem taşımaktadır. Bunun yanında yer altı madenciliği açısından havalandırmanın sisteminin kurulması ve tahkimatın yapılması büyük önem taşımaktadır..." (İmbat A.Ş. Yetkilisi, 2018)

“..Maden ocağında tahkimatın madenin yapısına göre, demirden, çelikten veya ahşaptan yapılmaktadır. Tahkimat maden ocaklarının güvenliği açısından çok önemlidir. Tahkimatta ufak bir sıkıntı olması durumunda MIGEM faaliyetin durdurulmasina karar vermektedir. Bu şekilde maden sahasının güvenlik ve emniyetinin sağlanması açısından sürekli denetimler yapılmaktadır.."(Soma Kömür Işletmeleri A.Ş. Yetkilisi, 2018)

“....Yer altı madenlerinde iş sağll̆̆g ve güvenliğinin sağlanması açısından çalışanlara eğitim verilmesi ve çalışanların da bu eğitimlere düzenli iştiraki oldukça önemlidir. Bu nedenle işçilere sık sı iş sağlı̆̆l ve güvenliği eğitimleri verilmekte ve işçilere gerekli bilgilendirmeler yapılmaktadır. Bu eğitimlerin düzenli bir şekilde periyodik olarak yapılmasına özen göstermekteyiz. Ayrıca, verilen eğitimler kamera ile kayıt altına alınmaktadır. Bunun yanında, işçilere eğitimlerin verilip verilmediğini denetlemek üzere ayda iki kez müfettişler incelemeler yapmaktadır. Isşçilere uygun işs săglı̆̆ ve güvenliği eğitimleri verilmesi için azami dikkat göstermekteyiz. Soma maden faciası döneminde yaşanan üzücü tablodan büyük ders çıkardık. Doğrusunu söylemek gerekirse, Soma maden faciası sonrasında iş sağlığl ve güvenliği eğitimlerine daha bir çok önem vermeye başladık. Soma maden faciası yaşanmadan önce iş să̆lı̆̆l ve güvenliği eğitimleri noktasında birtakım eksikliklerimiz bulunmaktaydl...." (Işsveren, 2018)

ISGK kapsamında soma madenlerinde ISSG anlayışı. Soma maden faciası sonrası dönemde Soma madenlerinde İSK doğrultusunda iş sağlığı ve güvenliği eğitimleri ve bu yönde yapılan bilgilendirmelerde yeni bir anlayış benimsenmiştir. Buna göre, Soma madenlerinde çalışanlara çeşitli sınıflarda iş sağlığı ve güvenliği eğitimleri verilmektedir. Ayrıca, burada çalıştırılacak işçiler kalifiye işçiler arasından seçilmektedir. Yer altında ve yer üstünde bulunan makinelerin kullanımında gerekli belgeleri ve sertifikaları olan işçiler ya da 
gerekli eğitimleri almış kişiler çalıştııılmaktadır. Ancak, Soma maden faciası yaşanmadan önceki süreçte maalesef madenlerde niteliksiz işgücü çalıştırılmış ve iş sağlığ1 ve güvenliği eğitimlerine önem verilmemiştir.Maalesef, İSGK bağlamında yeni iş sağlı̆̆ 1 ve güvenliği anlayışı Soma maden faciası yaşanınca gereken önemi görmüştür. Bir başka ifadeyle, İSGKnin yürürlüğe girmesi ile birlikte benimsenen yeni iş sağ $\breve{g ̆}_{1}$ ve güvenliği anlayışı Soma maden faciasından sonra Soma madenlerinde daha belirgin olarak karşılık bulmuştur. $\mathrm{Bu}$ doğrultuda, iş sağllğı ve güvenliği açısından önleyici sistemin önemi anlaşılmıştır. Örneğin, Soma maden sahasında görev yapan bir yetkili,

“..6331 sayılı İSGKnin yürürlüğe girmesi ile birlikte önleyici bir sistem kabul edilmiştir ve risk ortaya çıkmadan gereken tedbirlerin alınması amaçlanmıştır. Soma madenlerinde de İSGKnin yürürlüğe girmesi ve ardından yaklaşık iki yıl sonra Soma maden faciasını yaşanması ile birlikte iş kazası ve meslek hastalıklarının yaşanmaması açısından önleyici bir sistem oluşturmanın önemi daha iyi anlaşılmıştır. Bu nedenle önceliklerimizden biri de işçilerin madene girmeden önce, bedenen ve zihnen sağlıklı olmasına dikkat etmekteyiz. Bu nedenle, yer altında çalışacak işçinin uykusunu almış, moralli bir şekilde maden ocağına girmesi gerekmektedir. İşçinin tahkimata geldiğinde yorgun olmaması oldukça önemlidir. Aksi takdirde verimi düşmektedir. İşçi, maden ocağına uykusuz gelirse o gün çalıştırılmamaktadır ve geri gönderilmektedir. Ayrıca, yer altında çalışan işçilerin beslenmesine de dikkat etmesi gerekmektedir. İşçinin düzgün beslenmemesi durumunda verimi düşmektedir. Bunun yanında maden ocağında çalışacak işçinin baş dönmesi, mide bulantısı, halsizlik ya da başka bir sağlık sorunu olup olmadığı kontrol edilmektedir. Madende çalışacak işçiler açısından bu denetimler yapılırken, maden ocağında da ileride yaşanması muhtemel iş kazası ve meslek hastalıklarını önlemek adına oluşabilecek riskler önceden incelenmektedir ve raporlanarak kayıt altına alınmaktadır. Bu bağlamda maden sahasında kullanılan makinelerde bir arıza olup olmadığı, maden sahasında yapılan tahkimatların sağlam olup olmadığı, yanıcı ve patlayıcı maddelerin kontrolü gibi alanlarda incelemeler yapılmaktadır....” (Maden Mühendisi, 2018)

\section{Sonuç}

Soma madenleri ülkemizin en geniş linyit rezervlerine sahip maden sahasıdır. Bu nedenle, ülke ekonomisinde oldukça önemli bir yere sahiptir. 
Ayrıca, Soma madenleri sahip olduğu linyit rezervleri dolayısıyla ülkemizde geniş istihdam alanları yaratmaktadır. Ancak, son yıllarda Soma madenleri üzücü bir şekilde zihinlerde canlanmaktadır. Bu durumun ortaya çıkmasında özellikle, 2014 yılında 301 madencinin acı bir şekilde hayatını kaybettiği kaza oldukça etkili olmuştur. Bundan sonraki süreçte de Soma madenleri bu kaza ile anıla gelmiştir. Ancak, toplum vicdanını yaralayan bu elim hadiseden sonra Soma madenlerinde birtakım yeni iş sağlığ 1 ve güvenliği yöntemleri uygulanmaya başlanmıştır. Bu anlayış doğrultusunda, beden gücünden ziyade, makinelerin etkin kullanıldığı bir sistem uygulanmaya başlanmıştır. Bu şekilde iş sağlığı ve güvenliği tesis edilmek istenmiştir. Ancak, burada da makinelerin kullanımından kaynaklı dikkatsizlik nedeniyle kazalar yaşanmaya devam etmiştir. Bunun yanında, madenlerde iş sağlı̆̆ 1 ve güvenliğinin sağlanması açısından havalandırma, basınç kontrolü, ortam sicaklığını dengeleme, koruyucu donanımların kullanımı gibi konularda da birtakım yenilikler yapılmıştır. Dolayısıyla, Soma maden sahasında genel olarak iş sağlı̆̆ı ve güvenliğinin sağlanması adına çeşitli yöntemler uygulanmaktadır. Ayrıca, işçilere iş sağlığı ve güvenliği eğitimleri de verilmektedir. Burada verilen eğitimlerde temel konulardan başında güvenlik uygulamaları gelmektedir. Zira, maden sahasında bir işçinin dikkatsizliği sonucu büyük tehlikeler ortaya çıkabilmektedir.

Sonuç olarak, Soma madenlerinde Soma maden faciası sonrası dönemde birtakım yenilikler uygulamaya geçse de, Soma madenlerinde iş sağlı̆̆ ve güvenliği uygulamaları açısından çeşitli eksiklikler varlığını sürdürmektedir. İş sağlı̆̆ 1 ve güvenliği anlayışının Soma madenlerinde tam olarak hayata geçirilememesinde, işverenin yanında çalışanların da kusuru bulunmaktadır. İşverenler, tam anlamıyla iş sağlığı ve güvenliği önlemlerinin alındığ bir çalışma ortamı oluşturamamakla birlikte, çalışanlar da üzerine düşen dikkat ve özen yükümlülüğünü yerine getirememektedir. Bu nedenle, Soma madenlerinde halen irili ufaklı iş kazalarının yaşandığı görülmektedir. 


\section{Kaynakça/References}

Andaç F. (2015). Maden İşyerlerinde İş Sağlığı ve Güvenliği Önlemleri ve Zorunlu Sendikalaşma, Sarı S., Gencer A. H., Sözen i. (Ed.), International Conference On Eurasian Economies. (ss. 601-605)

Akdeniz, A. L. (2015), Meslek Hastalı̆̆ Kavramı Üzerine, İstanbul; Beta Yayıncılık.

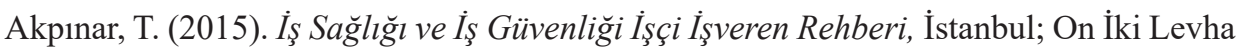
Yayıncilik.

Akpınar, T. (2018). İş Sağllğg ve Güvenliği Hukuku, Ankara: Ekin Kitapevi.

Alper, Y. ve Kılkış, İ. (2017). Işs ve Sosyal Güvenlik Hukuku, Bursa: Dora Yayıncılık.

Atasayar, M. (1990). TKİ Kurumu ELI Müessesesi Linyit Üretim Faaliyetleri, Madencilik, $X X I X, 5-16$.

Balkır, Z. G. (2012),İş Sağlığı ve Güvenliği Hakkının Korunması: İşverenin İş Sağlığı ve Güvenliği Organizasyonu, Sosyal Güvenlik Dergisi, 2, 56-91.

Baloğlu, C. (2015). Çalışanların İş Sağlığı ve Güvenliği Yükümlülükleri ve Ayrımcılığın İş İlişkilerine Etkisi, Kamu İş, 14, 17-28.

Baybora, D. (2012). İş Sağlığı ve Güvenliğine Genel Bakış, Baybora D. (Ed.), $\dot{I}_{s ̧}$ Sa $\breve{g} l ı \breve{g} l$ ve Güvenliği, Eskişehir: Anadolu Üniversitesi Yayınları.

Baycık, G. (2011). Rödovans Sözleşmesinin Hukuki Niteliği ve Tarafların İş Sağlığı ve Güvenliği Yükümlülükleri, Sarper Süzek'e Armağan, II.1895-1996.

Bolat, Y. Z. (2015). Kamu Kurumlarında Acil Durum Planı Hazırlama Rehberi ve İlgili Sektörde Acil Durum Bilincini Arttırmaya Yönelik Uygulama”, Çalışma ve Sosyal Güvenlik Bakanlığg İş Sağlığı ve Güvenliği Genel Müdürlüğü, İş Sağlığ1 ve Güvenliği Uzmanlık Tezi, Ankara, 2015.

Can, H., Yuvka, E. Ş. ve Beyhan, S. (2015). Yer altı Madenciliğinde Risk Değerlendirme

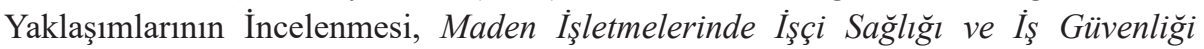
Sempozyumu 2015 Bildirimler Kitabı, Adana: TMMOB.

Çankaya, O. G. (2014). Rödovans Alt İşverenlik Sözleşmesi midir? Kamu-İş, 13, 1-21.

Demirbilek, T. ve Çalık Ö. (2008). Kişisel Koruyucu Donanım Kullanımını Etkileyen Bireysel ve Örgütsel Değişiklikler, Dokuz Eylül Üniversitesi İktisadi ve İdari Bilimler Fakültesi Dergisi, 23, 169-190.

Düzgün, Ş. (2016). Kasti Körlük: Soma Faciası https://bilimakademisi.org/wp-content/ uploads/2016/02/soma-raporu-2016.pdf(30.05.2019).

Erekmekci, M. ve Süleymanoğlu G. (2016). Rödovans Sözleşmesi, İstanbul Barosu Dergisi, 90, 133-144.

Ergun, A. R. (2007). Yer Altı Maden İşletmelerinde Gaz ve Toz Patlamaları ve Önlemler, (İş Sağlığı ve Güvenliği Uzmanlık Tezi), ÇSGBİSGM , Ankara.

Eser, A. (2015). Maden İşlerinde Solunumu Koruyucu Donanımlar, Maden Işletmelerinde Işçi Sağliğl ve İş Güvenliği Sempozyumu 2015 Bildirimler Kitabı, Adana: TMMOB.

Eyrenci, Ö., Taşkent S. ve Ulucan D. (2017). Bireysel Işs Hukuku, İstanbul; Beta Yayınevi. 
Gerek, N. (2014),İş Kanunu İle Bazı Kanun ve Kanun Hükmünde Kararnamelerde Değişiklik Yapılması İle Bazı Alacakların Yeniden Yapılandırılmasına Dair 6552 Sayılı Kanunun Düşündürdükleri, TÜHiS İş Hukuku ve İktisat Dergisi, 25, 1-20.

Gerek, N. (2015). Yer altı Maden İşletmelerinde Çalışanlarla İlgili Yeni Düzenlemelerin Düşündürdükleri. Кати-İs, 14,1-27.

Günay, C. İ.(2012). Türk Borçlar Kanunu Şerhi, Ankara; Yetkin Yayınları.

Güzel, A. ve Okur, A. R. ve Caniklioğlu, N. (2016). Sosyal Güvenlik Hukuku, İstanbul: Beta Yayıncilık.

http://www.mta.gov.tr/v3.0/kurumsal/tarihce(09.03.2019).

https://www.ilo.org/dyn/normlex/en/f?p=NORMLEXPUB:12100:0::NO::P12100_ INSTRUMENT_ID:312321 (15.03.2019).

İnciroğlu, L. (2017). İş Sağllğı ve Güvenliği Mevzuatı, Ankara: Seçkin Yayıncılık.

Kamu Denetçiliği Kurumu. (2014). Soma Maden Kazasından Hareketle Kömür Madenciliğinde Iss Să̆lığ ve Güvenliği Özel Raporu. Ankara.

Karakaş, İ. (2015). İş̧̧i Açısından İş Sağlığı ve Güvenliği Uygulamaları, İş Sağlğ̆l ve Güvenliği Ders Notlarl (2014), Ankara: Gurup Matbaacilık.

Korkmaz, F. Ve Alp, N. S. (2016). Bireysel İş Hukuku,Ankara: Seçkin Yayıncılık.

Kaştan, Y. (2016). Osmanlı İmparatorluğunda Kömür Ocaklarının İşletilmesi (18321918), Osmanlı Medeniyeti Araştırmaları Dergisi, 2, 1-26.

Kurt, R. (2013). Herkes İçin İşS Sağlğ̆ ve Güvenliği Rehberi, Ankara: Seçkin Yayıncılık.

Maden İşletmeleri Grubu. (2016). Risk Değerlendirme Bülteni, Risk ve Madencilik Grubu, 5, 1-29.

Narter, S. (2017). İ̧ Kazası ve Meslek Hastalı̆̆ında Hukuki ve Cezai Sorumluluk, Ankara; Adalet Yayınevi.

Önder, S., Önder, M. ve Günaydın, E. (2017).Maden Sektörü Çalışanlarının Kişisel Koruyucu Donanım Kullanmalarının Değerlendirilmesi, Altıner M., Özdemir A. C. (Ed.).Uluslararası Maden Işsletmelerinde İş̧̧i Sağlğ ve İş Güvenliği Sempozyumu 2017, Adana: TBMM Maden Mühendisleri Ofisi.

Özdemir, E. (2014). İş Sağllğı ve Güvenliği Hukuku, İstanbul: Vedat Kitapçılık.

Özdemir, C. Ş. (2018). İş Mevzuatı Rehberi, Ankara: Adalet Yayınevi.

Öztoprak, S. (2015). Maden Ocaklarının Özel Hukuk Kişileri Tarafindan İşletilmesi, Ankara; Yetkin Yayınevi.

Öztürk, G. S. (2015). İs Sağllğı ve Güvenliği Yükümlülüklerinin Yerine Getirilmemesinin Hukuki, İdari ve Cezai Sonuçları, İstanbul: Beta Yayınc1lık.

Özveri, M. (2015). İş̧̧i Sağllğ İş Güvenliği ve İş Cinayetleri, İstanbul: Birleşik Metal İş Yayınları.

Poyraz, E. (2016). IŞS Hukuku Şemalı Anlatıml, Ankara: Seçkin Yayıncılık.

Selek, H. S. (2018). İ̧s Sağllğı ve Güvenliği (ISG) Temel Konular, Ankara: Seçkin Yayıncılik. 
Senyen Kaplan, E. T. (2015).Bireysel İ̧̧ Hukuku, Ankara: Gazi Kitapevi.

Sevimli, K. A. (2013). Türk borçlar kanunu m. 417 ve iş sağlığı ve güvenliği kanunu 1şığında genel olarak işçinin kişiliğinin korunması. Çalışma ve Toplum, 36, 107-148.

Sümer, H. H. (2017). İş Să̆lı̆̆l ve Güvenliği Hukuku, Ankara: Seçkin Yayıncılık.

Süzek, S. (2017). İş Hukuku, İstanbul: Beta Yayıncılık.

Şen, M. (2015). İş sağlığ 1 ve güvenliği kavramı, tarihsel gelişimi ve dayanakları, MÜHFD, 4, 117-142.

TBMM. (2014). Meclis Araştırma Komisyonu Raporu, Yasama Dönemi; 24, Yasama Y111; 5, Sira Sayıs1; 680, Ankara: TBMM.

Tezel, A. ve Kurt, R. (2009). Sosyal Güvenlik Reformu, Ankara: Yaklaşım Yayıncılık.

Tiftik, M. ve Adıgüzel A. (2016). İş sağlığı ve güvenliği kanunu'na göre genel hizmet sözleşmelerinde işverenin işçiyi koruma borcu. Yıldırım Beyazıt Hukuk Dergisi, 1(1), 319-366.

TMMOB Maden Mühendisleri Odası. (2014). Soma Maden Faciası TMMOB Raporu, Ankara: TMMOB.

TMMOB. (2018). Iş̧çi Sağlı̆̆l ve İş Güvenliği Oda Raporu, Ankara: TMMOB.

Topaloğlu, M. (2014). Maden Kazaları Karşısından Maden Ruhsat Sahibinin ve Rödovansçının Hukuki Durumu, Sektörden Haberler Bülteni, Türkiye Madenciler Derneği, 52.

Türkiye Barolar Birliği İnsan Hakları Merkezi. (2014). Soma Maden Faciası Raporu, Ankara: Türkiye Barolar Birliği.

Türkiye Maden İşçileri Sendikası. (2010). Madencilik Sektöründeki Sorunların Araştırılarak Alınması Gereken Önlemlerin Belirlenmesi Amacıyla Kurulan Meclis Araştırma Komisyonuna Sunulan Türkiye Maden İşçileri Sendikası'nın Görüşleri, Ankara.

Türk Sosyal Bilimler Derneği. (2016). İki Yılın Ardından Soma Maden Faciası Raporu, Ankara.

Turhan, M. (2016). Türkiye'de Maden Hukukunun Tarihi Gelişimi ve Bazı Ülkelerle Mukayesesi, Ballı (Der.). Maden Hukuku Bildirimler Kitabı, Ankara: Astana Yayınları.

Uluslararası Çalışma Örgütü. (2016). Türkiye Kömür Madenciliği Sektöründe Sözleşmesel Düzenlemeler: Gerçekleşme Biçimleri, Boyutları, Nedenleri, Yasal Nedenleri ve İSG Üzerindeki Etkisi, Ankara; ILO Türkiye Ofisi.

Ulusoy, M. E. (2013). İşverenin Işs Sağliğı ve Güvenliği Açısından İşyerinde Örgütleme Yükümlülü̈̆̈̈, (Yüksek Lisans Tezi), Selçuk Üniversitesi, SBE, Konya.

Üçışık Erbilen, S., \& Şahin G. (2015). Energy geography within the scope of the lignite in Türkiye. Doğu Coğrafya Dergisi, 20, 135-160.

Yamakoğlu, E. (2016). İşverenin İşyeri Hekimi İş Güvenliği Uzmanı Çalıştırma Yükümlülü̈̆̈̈, Ankara: Seçkin Yayıncılık.

Yeşilyurt, C. (2015), İş Kazaları ve Maden Mevzuatı, Madencilik Türkiye, 6, 108-116. 
Yılmaz, F. (2013). 6331 sayılı iş sağlığı ve güvenliği kanununda önleyici yaklaşım ve işverenin yükümlülükler. TÜHIS İş Hukuku ve İktisat Dergisi, 24, 44-66.

Yıldız, T. D. (2012). 3212 Sayılı Maden Kanunu Öncesinde ve Sonrasında Türkiye'de Maden Mevzuatında Yapılan Değişikliklerin İncelenmesi, (Yüksek Lisans Tezi), İTÜ, FBE, İstanbul.

Y.HGK, E.2013/21-102, K.2013/1456, T.09.10.2013, http://www.kazanci.com/kho2/ibb/ giris.htm, (05.03.2019).

Y.21.HD, E.2016/15802, K.2017/3195, T.18.04.2017, http://www.kazanci.com/kho2/ibb/ giris.htm (07.03.2019).

Y.9.HD, E.2015/3000, K.2015/12939,T.02.04.2015, https://www.incirogludanismanlik. com/2015/10/09/ 2010-2017-yillari-9-hd-yargitay-kararlari/ (10.03.2019).

YHGK, E.2004/21-365, K.2004/369, T.16.6.2004, http://www.hukuki.net/ictihat/ Yargitay_Hukuk_Genel_Kurulu_21_365.php (14.03.2019). 